\title{
T-Cell Signaling in HIV-1 Infection
}

\author{
Wasim Abbas and Georges Herbein ${ }^{*}$
}

\author{
Department of Virology, Pathogens \& Inflammation Laboratory, UPRES EA4266, SFR FED 4234, University of \\ Franche-Comte, CHRU Besançon, F-25030 Besançon, France
}

\begin{abstract}
HIV exploits the T-cell signaling network to gain access to downstream cellular components, which serves as effective tools to break the cellular barriers. Multiple host factors and their interaction with viral proteins contribute to the complexity of HIV-1 pathogenesis and disease progression. HIV-1 proteins gp120, Nef, Tat and Vpr alter the T-cell signaling pathways by activating multiple transcription factors including NF-кB, Sp1 and AP-1. HIV-1 evades the immune system by developing a multi-pronged strategy. Additionally, HIV-1 encoded proteins influence the apoptosis in the host cell favoring or blocking T-cell apoptosis. Thus, T-cell signaling hijacked by viral proteins accounts for both viral persistence and immune suppression during HIV-1 infection. Here, we summarize past and present studies on HIV-1 Tcell signaling with special focus on the possible role of $\mathrm{T}$ cells in facilitating viral infection and pathogenesis.
\end{abstract}

Keywords: Apoptosis, HIV-1, Nef, reservoirs, T cells, viral proteins.

\section{INTRODUCTION}

The ineffective cell-mediated and humoral response to HIV-1 infection results in partial control of viral replication that ultimately leads to chronic immune activation and systemic depletion of CD4+ T cells [1]. The long period of time between infection and development of AIDS reveals that only a small fraction of CD4+ T cells which are infected during acute HIV-1 infection, elevates the death rates of T cells through direct or indirect (bystander T- cell apoptosis) manner, and are responsible for HIV disease progression [2]. Immune system struggles to recover the injury made by HIV during acute HIV-1 infection but HIV-1 develops highly effective strategies to overcome host immune system [3]. This struggle is further complicated by opportunistic infections [4]. This battle causes further damage to the immune system by providing fuel for viral replication that ultimately leads to the formation of viral reservoirs [5].

The primary infection is defined as the first period of infection from onset of disease until the formation of HIV-1 specific antibodies 3 to 4 weeks of infection [6]. During HIV transmission, dendritic cells (DCs) are first line of defense against viral penetration and wide spread dissemination [7]. DCs take up HIV via C-type lectin binding receptor and migrate to lymph nodes where they prime HIV-specific immune responses by presenting HIV-1 antigens to CD4+ T cells [8]. However, it has been recently reported that Siglec-1 is a key factor for HIV-1 spread via infectious DC/T-cell synapses [9-10]. Furthermore, it is likely that DCs contribute to HIV-1 dissemination throughout the body during early stages of infection due to their migratory potential [11]. Moreover, CD4+ T cells help CD8+ T cells and B cells in mounting cellular and humoral anti-HIV immune response.

*Address correspondence to this author at the Department of Virology, University of Franche-Comte, Hôpital Saint-Jacques, 2 place Saint-Jacques, F-25030 Besançon cedex, France; Tel: +33-381-21-88-77; Fax: +33-38166-56-95; E-mail: georges.herbein@univ-fcomte.fr
The plasma viremia increases to reach a peak after 21-28 days of infection together with depressed peripheral CD4+ T cell numbers [12]. This acute HIV-1 infection results in selective and dramatic depletion of CD4+ CCR5+ memory $\mathrm{T}$ cells predominantly at mucosal surfaces that have severe immunological consequences. During early SIV infection, up to $60 \%$ of memory CD4+ $\mathrm{T}$ cells in the intestinal lumina propria appear to contain SIV-RNA at the peak of infection at day 10 , with majority of these cells being eliminated by day 14 [12]. These results further characterize the early loss of memory CD4+ $\mathrm{T}$ cells in the mucosal associated lymphoid tissue (MALT), which follows SIV infection. Additionally, the infection of CD4+ T cells that express low level of CCR5 emphasizes the infection of resting memory CD4+ T cells and the loss of uninfected CD4+ T cells as a further mechanism of early $\mathrm{CD} 4+\mathrm{T}$ cell depletion in the MALT [12, 13].

At the peak of viremia, patients may develop symptoms of acute retroviral syndrome e.g., influenza like illness with fever, sore throat, lymphadenopathy and exanthema [14]. However, viral reservoirs have already been established in cells with slower rate of decay than $T$ cells, implying that virus cannot be eliminated by highly antiretroviral therapy (HAART) within the lifetime of the patient [15]. Immunological damages to gastrointestinal tract lead to breaks in the mucosal barrier allowing the translocation of microbial products into circulation that is responsible of chronic immune activation [16]. In this scenario, the ultimate consequence of immune activation is depletion of CD4+ and CD8 + T cells, abnormal T-cell trafficking, clonal exhausting of $\mathrm{T}$ cells and drainage of memory $\mathrm{T}$-cell pools [17]. In addition, the accelerated viral evolution at this stage provided by an excessively high viral mutation rate and alternation in cellular tropism, resulting in progression from a pool of CCR5 tropic to dual tropic or dominantly CXCR4 tropic strains with increase virulence and broader target cell tropism [17]. Damage to lymphoid tissue results in thymic 
dysfunction, transforming growth factor beta (TGF- $\beta$ ) dependent fibrosis and alteration in lymphoid architecture [18].

The chronic phase of HIV-1 infection that last for several years, is the major driving force behind CD4+ T-cell depletion and strong predictor of disease progression [19]. CD4+ T-cell activation provides new targets for HIV-1 replication, in such way creating a favorable environment for further virus mediated damage to the immune system and chronic consumption of the pools of naïve and resting memory cells [20, 21]. Furthermore, the chronic activation and proliferation of $\mathrm{T}$ cells may result in perturbations of cell cycle control and an increased susceptibility to undergo activation induced apoptosis [22]. HIV-1 exploits the T-cell signaling for productive infection and destruction of immune cells, and the understanding of T-cell signaling becomes prime important to study the HIV-1 pathogenesis more effectively.

\section{HIV-1 PROTEINS AND T-CELL SIGNALING}

HIV-1 viral proteins can activate multiple signaling pathways within the target cell to facilitate viral life cycle at different stages. Each viral protein is unique and plays an important role in HIV-1 persistence and pathogenesis. In early stages of infection the viral encoded proteins, particularly Nef, gp120, Tat and Vpr, mimic T-cell signaling pathways which results in sustained viral replication within infected T cells (Fig. 1). Furthermore, these HIV-1 proteins favor the inhibition of T-cell apoptosis by inhibiting "Outside in" and "Inside in" apoptotic signals in HIV-1 infected $\mathrm{T}$ cells. At more advanced stages of the disease, HIV-1 viral proteins could favor immune suppression resulting in dramatic induction of $\mathrm{T}$-cell apoptosis both in infected and uninfected bystander T cells. In this section we will discuss main players of HIV-1 proteins (gp120, Nef, Tat and $\mathrm{Vpr}$ ) that interact with T-cell signaling (Fig. 1).

\section{Nef}

The HIV-1 Nef gene encodes a protein of $27 \mathrm{kDa}$ that is abundantly expressed early during viral life cycle [23]. Nef is a fascinating protein that is readily accessible for interaction and also capable of undergoing conformational changes for transient binding interactions [24]. In addition, HIV-1 Nef acts as a adaptor protein that connects several

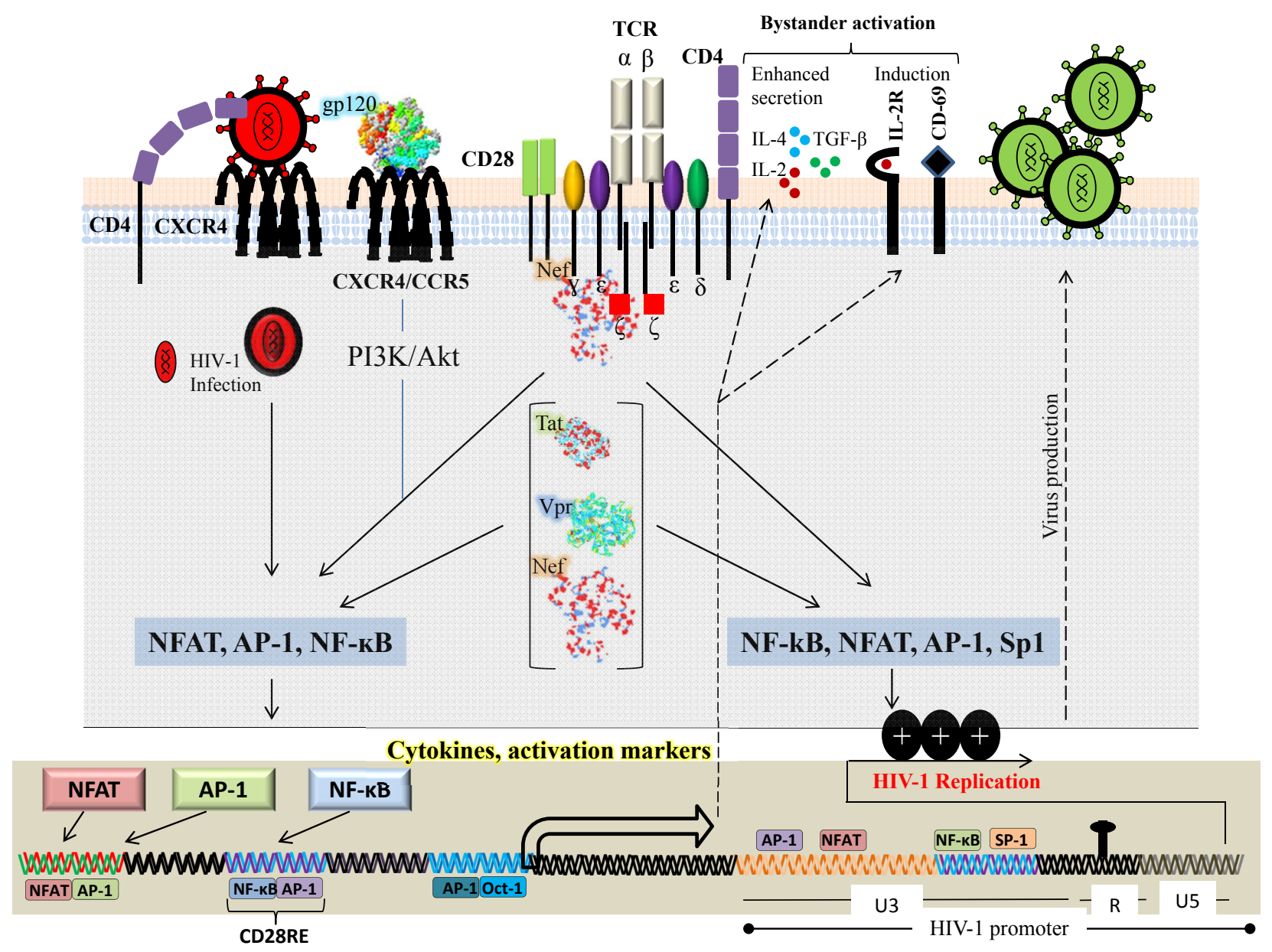

Fig. (1). T-cell signaling modulation by HIV-1 proteins. HIV-1 viral proteins modulate several transcription factors and surface receptors from infected CD4+ T cells that facilitate HIV-1 infection and pathogenesis. HIV-1 viral proteins (gp120, Nef, Tat and Vpr) induce downstream signaling events to activate nuclear factor of activated T cells (NFAT), nuclear factor kappa B (NF-кB), activator protein 1 (AP1) and specificity protein 1 (Sp1), and to induce the efficient transcription of HIV-1 (via its long terminal repeat (LTR)), cytokines and activation markers. 
cellular proteins and signaling complexes in a timely and well defined manner [25]. Nef down-regulates the cell surface receptors CD4 [26], CD28 [27], CD3 (only in SIV) [28] and major histocompatibility complex (MHC) class I, A and B [29] and upregulates FasL [30-32]. In addition to its expression in virally infected cells, Nef is also present in the extracellular environment and can reach concentration of up to $10 \mathrm{ng} / \mathrm{ml}$ in the sera of HIV-1-infected individuals [33]. This concentration may be higher in lymph nodes where virion trapping dendritic cells as well as virion infected CD4+ T cells and antigen-presenting cells (APC), are tightly packed $[34,35]$. Infected cells may release Nef through nonclassical secretory pathway or after lysis. Moreover, bystander cells may internalize Nef via endocytosis, pinocyotsis or other yet undefined mechanisms. However, it has been reported that HIV-1 Nef protein modulates the expression of a significant number of genes as early as two hours after treatment [36].

HIV-1 Nef protein activates T-cell signaling pathway and was originally described in 1994 using Jurkat cells stably transfected with CD8-Nef chimeric protein [37]. Cells that had higher concentration of CD8-Nef at the plasma membrane induced tyrosine phosphorylation and upregulation of activation markers such as CD69 [37]. In addition, activated Jurkat $\mathrm{T}$ cells die by activation induced apoptosis, and only cells with mutated nef genes expressing truncated Nef survived, indirectly confirming that Nef activated these cells [37]. Additionally thymocytes of transgenics expressing Nef under control of CD4 promoter exhibit constitutive tyrosine phosphorylation of LAT and p42/44 MAP kinase and CD3 hyperactivity [38]. Moreover, NFAT activity is increased in highly pathogenic strain of SIV, SIVmac239, containing a Nef variant with a functional immunoreceptor tyrosine-based activation motif (ITAM) [39]. The impact of Nef on T-cell activation was further investigated in which it was demonstrated that Nef associates with membrane microdomains critically involved in the initiation and propagation of $\mathrm{T}$-cell signaling. This raft association was required for Nef-mediated activation of NF$\mathrm{KB}$, NFAT, IL-2 and HIV-1 long terminal repeat (LTR) stimulation following CD3/CD28 costimulation [40, 41]. These results were further confirmed by gene expression profiling of inducible T-cell lines, showing that Nef and antiCD3 mediated T-cell activation overlaps by 97\% [42]. Moreover, it has been recently reported that HIV-1 Nef modulated the TCR functions either positively or negatively depending upon the activation state of infected T cells [43].

The direct interaction of Nef with both the T-cell receptor and its immediate downstream effectors has been reported [44]. Functional as well as binding studies analyzed the interaction of Nef with the T-cell receptor-chain [45], and proteins of the T-cell environment, like adaptor protein Vav [46] and LAT [38], the tyrosine kinase Lck [47], the serine kinase Pak [48], PKC [49], the DOCK2-ELMO1 complex [50], the map kinase ERK1 and ERK2 [51], and membrane microdomains [40]. Nef is a modular protein containing a myristoylated $\mathrm{N}$-terminus, a core domain and a polyproline motif. The polyproline motif acts as an SH3 binding domain that is highly conserved in viral isolates. This domain is capable of mediating association with Src kinase [52], and alters the catalytic activity of different kinases such as Lck and Hck [47-53]. Furthermore it also facilitates Nef binding to Vav and Vav2, which results in cytoskeletal changes and activation of JNK signaling pathways [46]. In addition, the polyproline motif has been shown to regulate the interaction with TCR $\zeta$-zeta chain [45-54]. The core domain of HIV-1 Nef protein contains di-arginine motif that allows the functional interaction with PAK kinase associated with increased viral infectivity $[55,56]$.

Nef mediated T-cell activation seems completely fulfill the needs of HIV, as one of the very early finding was that $\mathrm{T}$ cells have to be activated for HIV-1 replication and infection to start [57]. As quiescent $T$ cells do not support efficient retrotranscription, integration, expression of HIV genome due to low level of nucleotides, ATP and nuclear transcription factors $[58,59]$. Nef mediated T-cell activation leads to nuclear translocation of transcription factor such as NFAT and NF-KB, activating the viral promoter or establishing a basal viral transcription that would leads to the expression of more Tat protein [60]. However, HIV does express Nef before virus integration [23], but the viral replication in resting CD4 $\mathrm{T}$ cells is very low. The stimulation of TCR by antibodies activates viral replication. Although, Nef alone may not result in optimal viral replication [61], it may do with some additional cellular support that comes from macrophages or DCs. In immature DCs, HIV-1 replicates at a very low level. However, upon co-culture with resting $\mathrm{T}$ cells, a significant viral replication is observed in the $\mathrm{T}$ cells that require a functional nef gene $[62,63]$. In addition, macrophages play a supporting role for HIV-1 replication. Infected macrophages secrete chemokines (MIP-1 $\alpha$ and MIP-1 $\beta$ ) in a Nef-dependent manner. The released chemokines attract the resting $\mathrm{T}$ cells and stimulate them for productive infection [64, 65]. Moreover, immature DCs also attract $\mathrm{T}$ cells in a Nef-dependent manner by upregulating DC-SIGN [66].

Survival strategies are more important for invading pathogenic viruses, in particular when they establish a chronic infection [32]. HIV-1 through Nef interferes with MHC molecules, modulates cytokine activity, and induces apoptosis by FasL [32, 67]. In HIV-infected cells, the Nef expression leads to the upregulation of FasL, which could potentially stimulate the Fas receptor in an auto/paracrine fashion. Such a mechanism leads to the destruction of infected cells that overexpress Fas [44, 68]. Additionally, HIV-1 gp120 ligation of CXCR4 on macrophages induces upregulation of membrane bound TNF, triggering cell death via $\mathrm{TNFR}$ in adjacent $\mathrm{CD} 8+\mathrm{T}$ cells which leads to $\mathrm{CD} 8+\mathrm{T}$ cell depletion [69].

HIV-1 Nef manages the apoptotic signal from cell surface receptors through association and blockade of apoptosis signal regulating kinase 1 (ASK1) [70]. ASK1 links both the Fas and TNFR mediated signals to downstream JNK/p38 pathways. ASK1 kinase activity is inhibited by thioredoxin (Trx), a redox regulator protein. Only a reduced form of Trx associates with ASK1 and keeps the kinase inactive [71]. HIV-1 Nef targets the ASK1 by blocking the release of Trx from ASK1 [70]. Nef signaling also interferes with the regulation of intrinsic cellular death pathway by Bcl family of proteins. HIV-1 Nef associates with and activates PI3K but not to stimulate Akt, but, rather to activate Nef-associated serine kinase Pak [72]. The NefPI3K-PAK complex phosphorylates Bad on serine residues, 
resulting in block of apoptosis induced by serum starvation and, more importantly, by HIV replication [72]. In this way, Nef manages the difficult task like keeping the cell alive until next generation of virus is ready to strike.

\section{HIV-1 gp120}

The gp120 molecule of HIV-1 is a glycoprotein, essential for viral infection as it facilitates HIV entry into the host cells [73]. HIV-1 gp120 is shed from the viral membrane and accumulates in lymphoid tissues in significant amounts [74], e.g. where it can induce apoptosis and severely alter the immune response to the virus by dampening the antiviral CTL response thus impeding the clearance of HIV [75]. Binding of HIV envelope to its chemokine coreceptors (CXCR4, CCR5) mediates two major biological functions: membrane fusion and signal transduction. Apart its function in facilitating viral entry, it is becoming increasingly evident that gp120 plays a much greater role in HIV pathogenesis [76]. The binding of viral envelope to its chemokine receptors, CXCR4 and CCR5, not only mediates entry but also activates multiple intracellular signaling cascades, a process mimicking chemokine signaling through binding to their cognate receptors [77]. The coreceptor CCR5 is used during early infection whereas the virus utilizes the CXCR4 coreceptor during later infection in $40 \%$ of patients [78, 79]. The X4 and R5 envelopes (expressed on infected cells] can induce rapid tyrosine phosphorylation of the protein tyrosine kinase Pyk2 through binding to CXCR4 or CCR5 [80]. Pyk2 phosphorylation is frequently associated with $G$ protein signaling and calcium flux [81]. Chemokine receptor signaling is coupled with distinct pathways that mediate cell migration, transcriptional activation, cell growth and differentiation. CXCR4 activates phospholipase C- $\gamma$ (PLC- $\gamma$ ) that leads to calcium flux and activation of protein kinase $\mathrm{C}$ (PKC). PKC signaling is important for SDF- $\alpha$ chemotaxis. During viral entry, HIV-1 gp120 binding to CXCR4 or CCR5 activates a number of signaling molecules common to chemokine mediating signaling. In addition to Pyk2 activation, gp120 triggers the activation of PI3K, Akt [82, 83], Erk-1/2 [83] and CD4/CXCR4 dependent NFAT nuclear translocation [84].

HIV-1 gp120 mediates chemotaxis, actin cytoskeleton rearrangement and the activation of an actin depolarization factor, cofilin, to increase the cortical actin dynamics in resting CD4+ $\mathrm{T}$ cells [77]. Moreover, recombinant viral envelope induces viral replication in culture of resting of CD4+ T cells of infected patients [85]. Furthermore, the HIV envelope enhances the viral infectivity by facilitating the nuclear import of pre-integration complex [86, 87]. Cofilin is involved in chemotaxis and T-cell activation [88]. In chemotaxis, cofilin is the main driving force for promoting the cortical actin dynamics central to cell migration [89]. In T-cell activation, cofilin is activated through CD28 costimulation, and plays a critical role in actin reorganization and formation of immunological synapse required for sustained T-cell activation [90]. The static cortical actin in resting CD4+ T cells is a unique barrier for viral post entry migration [91]. To overcome this restriction, HIV relies on gp120-CXCR4 signaling and activates cofilin to increase the cortical actin dynamics. This unique requirement is observed in resting CD4+ $\mathrm{T}$ cells, since in activated $\mathrm{T}$ cells cofilin is constitutively active to facilitate the cell cycle driven actin remodeling [91].

Significant amounts of soluble gp120 are present in lymph nodes during chronic HIV infection [75]. T cells from these areas lose their ability to respond to gp120. Moreover, the regulatory $\mathrm{T}$ cells produce immunosuppressive cytokines such as TGF- $\beta$ upon stimulation of SHIV gp120 [75, 92]. Much of immunosuppressive activity of gp120 is mediated by its heavily glycosylated variable loops which contain mannose residues that inhibit the T-cell proliferation by inhibiting the ability of mature monocyte derived dendritic cells (mMDDC) to induce T-cell proliferation [93]. Accordingly, enzymatic removal of mannose moieties increases immune responses to gp120 [94].

\section{Tat}

HIV-1 Tat is virally encoded multifunctional protein, which plays a critical role in viral replication [95]. Tat is an early regulatory protein that has variable length of 86-104aa, encoded by two exons [96]. The first encodes residues 1 to 72 and is classically described as a modular protein, which is sufficient for Tat transactivation [95]. The second exon of Tat codes for amino acid 73-104, essential for NF-kB dependent HIV-1 LTR activation [97]. Mutational analysis of HIV-1 Tat has found two functional domains: an activation domain that mediates its interaction with cellular machinery and an arginine rich region that is required for binding to the transactivation responsive element (TAR) RNA [98]. The laboratory HIV-1 strains produce an active 86 aa Tat protein whereas most of Tat proteins from primary isolates contain an additional sequence at their C-terminus. The soluble form of Tat, which is released from productively infected unruptured cells as an extracellular protein and in the serum of HIV-1 infected individuals, is also able to enter in neighboring cells $[99,100]$. Specific Tat binding has been reported for three cell surface receptors including heparin sulphate, beta integrin and chemokine receptors. Studies of Tat derived peptides have shown that residues 48-60 from the protein transduction domain (PTD) account for the functional internalization into cells [101-103]. HIV-1 Tat is phosphorylated by CDK2 in vitro and in vivo. The Ser16 and Ser46 residues of Tat are potential phosphorylation sites. The phosphorylation of Tat is critical for HIV-1 transcription [104, 105].

HIV-1 Tat modulates the expression of several cellular genes [106]. Tat has been shown to upregulate the expression of IL-10 [107]. Furthermore, in vivo studies indicate that there is increase in IL-10 production in HIV-1 infected patients [108]. IL-10 inhibits the synthesis of TH1 and pro-inflammatory cytokines such as IFN- $\gamma$, IL-2, IL-3, TNF- $\alpha$ and GM-CSF $[109,110]$. It has been shown HIV-1 Tat protein suppresses gp- 120 specific T-cell response in IL10 dependent fashion. This immunosuppressive effect of Tat is not observed in IL-10 deficient mice demonstrating that the immunosuppressive effect of Tat is mediated through IL10 [107]. Additionally, HIV-1 utilizes the Tat protein to hijack the intracellular functions and evades the immune response of the host. It has been shown that secreted form of Tat from infected cells induces the expression of specific chemokine receptors such as CCR5 and CXCR4, which are important for HIV-1 infection [111]. Furthermore HIV-1 Tat 
activates uninfected naïve $\mathrm{T}$ cells (independent of antigen stimulation) and favors productive infection [112-114]. HIV1 Tat provides a reliable way for virus to compensate for the rapid destruction of activated permissive $T$ cells during the highly cytopathic infection. The soluble Tat protein enters into $\mathrm{T}$ cells and interferes with IL-7 signaling by downregulating the IL-7 receptor (CD127) [115]. IL-7 is essential for T-cell development and for maintaining homeostasis of mature T cells [116]. Furthermore, it has been reported that CD127 is downregulated on the surface of CD8+ T cells isolated from HIV-infected patients [117, 118]. Moreover, the treatment of recombinant, fully glycosylated simian IL-7 prevents the decline of circulating CD4+ T cells during acute phase of SIV infection in rhesus macaques [119]. HIV-1 Tat protein activates the MAPK pathways in primary $\mathrm{T}$ cells which is associated with the progression from G0 to G1 phase in naïve $\mathrm{T}$ cells facilitating productive HIV infection [112]. HIV-1 Tat upregulates the IL-2 production with CD3 or CD28 costimulation in T cells [120]. Moreover, HIV-1 Tat mediates the CD4+ $\mathrm{T}$ cells loss by recruiting the quiescent $\mathrm{T}$ cells in a reservoir that is permissive to productive HIV-1 infection and destruction by virus, and also induces apoptosis in uninfected $\mathrm{T}$ cells $[112,121]$. Finally HIV-1 Tat down-regulates the expression of several genes like the gene encoding major histocomptability (MHC) class I [122].

Tat has been shown to induce apoptosis of bystander CD4+ T cells by upregulating Fas ligand expression in both infected and uninfected bystander cells [123]. The $\mathrm{T}$ cells (CD4+ and CD8+ T cells) in HIV-1 infected individuals are more susceptible to Fas ligand induced apoptosis, as infected CD4+ T cells overexpress Fas and the proportions of these CD4+ $\mathrm{T}$ cells increase with the disease progression [124]. Therefore, the upregulation of FasL by Tat may lead to increased apoptosis in the antigen responding $\mathrm{T}$ cells that are overexpressing Fas [124, 125]. HIV-1 Tat protein associates and increases the transcription of phosphatase, PTEN and PP2A. The upregulation of these proteins in HIV-1 infected CD4+ $\mathrm{T}$ cells results in decreased amounts of pAkt and increased amounts of non-phosphorylated FOXO3, which activates the transcription of its proapoptotic target genes [126].

HIV-1 infection results in increased production of inflammatory cytokines (TNF- $\alpha$, IL-1, IL-6) that enhances viral gene expression and viral replication, and finally fuels virus spread [127-129]. The first exon of HIV-1 Tat increases gene expression of TNF by activating the TNF promoter [130]. Furthermore, T cells chronically infected with a pol-defective HIV-1 provirus constitutively express significantly higher levels of Tat and TNF [130]. Since TNF enhances the production of proinflammatory cytokines (IL-1 and IL-6) that ultimately enhances HIV-1 gene expression [128], thereby HIV-1 uses Tat protein and host factors to increase its own expression and infectivity to fuel disease [129].

IL-2 plays a very significant role in immune response and is regarded as a T-cell growth factor [131]. IL-2 has direct effects on the development and proliferation of lymphocytes, monocytes, macrophages and oligodendrocytes [131]. HIV-1 Tat protein upregulates the IL-2 gene expression and IL-2 secretion in Jurkat $\mathrm{T}$ cells and in primary $\mathrm{T}$ cells [132]. T- cell activation is known to be required for efficient viral replication and propagation [112]. Therefore, enhanced IL-2 secretion might enhance viral replication and spread [132].

\section{Vpr}

Viral protein $\mathrm{R}$ (Vpr), a 12-15-kDa virion-associated protein, is composed of 96 amino acids and is highly conserved in HIV-1 and SIV [133-135]. Vpr performs several functions such as nuclear import of viral preintegration complex, induction of G2 cell cycle arrest, modulation of $\mathrm{T}$-cell apoptosis, transcriptional coactivation of viral and host genes, and regulation of NF-KB activity [136]. $\mathrm{Vpr}$ is an essential HIV-1 protein for efficient infection in non-dividing cells [137] and enhances HIV-1 replication in T-cell lines and activated peripheral blood lymphocytes in vivo [138]. Recombinant Vpr stimulates the HIV-1 transcription from LTR and the formation of ion selective channels in lipid bilayers [139, 140].

$\mathrm{Vpr}$ protein is present in significant amount in the serum of AIDS patients [141]. Initially, it was observed that $\mathrm{Vpr}$ reactivates HIV-1 from latently infected cell lines and peripheral blood mononuclear cells of HIV-1 infected individuals [141, 142]. Moreover, later studies demonstrated that $\mathrm{Vpr}$ activates HIV-1 LTR as well as other cellular promoters [139, 143, 144]. The U3 region of HIV-1 LTR contains several activating elements such as NFAT, GRE, NRF, NF-KB and Sp1 [145-147]. Vpr transactivates the HIV1 LTR through the interaction with the cellular transcription factor Sp1 [144]. Sp1 is ubiquitously expressed and is involved in the transcription of a variety of cellular genes [148, 149]. However, other studies support the findings, that Vpr transactivates primarily the -278 to -176 region of LTR, which contains GREs, while the NF-kB and Sp1 are utilized by Tat mediated transactivation [150]. The $\mathrm{Vpr}$ mediated HIV-1 LTR transactivation plays an important role for immediate early expression of HIV-1 genome when alternative positive regulators are low [144]. HIV-1 Vpr binds to the transcription factor TFIIB and Vpr acts as a coactivator for transcription [143]. HIV-1 Vpr potentiates HIV1 LTR activation by forming a complex with p300 and TFIIH [151, 152]. Additionally, Vpr has also been reported to act cooperatively with HIV-1 Tat [153]. Therefore, the production of viral particle is likely increased via coactivation of HIV-1 LTR by Vpr. Moreover, Vpr binds to GR and activates GRE which in turn regulates the transcription of cellular genes which may increase HIV-1 replication and permissiveness [154].

Expansion of HIV-1 specific CD4+ $\mathrm{T}$ cells results in effective maintenance of immune system and contributes to control of viremia $[155,156]$. The presence of virus specific $\mathrm{CD} 8+\mathrm{T}$ cell response is essential for viral clearance during HIV-1 infection [155, 157]. Additionally, CD8+ T cell response can inhibit HIV-1 replication in vitro and also control the viral load in HIV-1 infected patients [158]. The loss in number of effective CD8+ T cells in HIV-1 infected patients has been correlated with reduced antiviral effects and disease progression in parallel with deterioration of immune system $[159,160]$. It has been reported that HIV-1 $\mathrm{Vpr}$ interferes with the development of antigen specific immunity [161]. It specifically inhibits the development of strong CD8+ CTL response and suppresses the Th1 immune 
responses by down-regulating IFN- $\gamma$ production. In the presence of $\mathrm{Vpr}$, there is an isotype shift towards $\mathrm{Th} 2$ response [161]. Moreover, Vpr reduces the efficacy of DNA and SIV-Nef vaccination in vivo, suggesting that $\mathrm{Vpr}$ may aid in evasion of immune response during HIV-1 [161, 162]. The mechanism of immune dysfunction caused by $\mathrm{Vpr}$ appears to involve the induction of apoptosis and cell cycle arrest in bystander $\mathrm{T}$ cells, contributing to the depletion of immune cells. While $\mathrm{Vpr}$ is seemingly anti-apoptotic in HIV-1 infected cell lines, however, in vitro studies suggest that bystander $\mathrm{T}$ cells may be induced to undergo apoptosis in response to extracellular or soluble $\mathrm{Vpr}$ [163-165]. Vpr alone has been shown to contribute to HIV-1 mediated immune dysfunction by promoting the depletion of thymic cells [166]. In addition to activation induced cell death by apoptosis of $\mathrm{CD} 4+\mathrm{T}$ cells, $\mathrm{Vpr}$ induces apoptosis by multiple mechanisms [167, 168]. Vpr increases Fas dependent caspase 8 activation in T cells to induce apoptosis, providing a potential mechanism for increased cell death. CD4 promoter in Vpr transgenic mice shows T-cell depletion in a Bcl-xL, Bax and caspase 1 dependent manner [169]. Vpr induces G2 cell cycle arrest that is associated with cell death [170]. This property depends on $\mathrm{Vpr}$ activated phosphorylation of Chk1, an event that begins during $\mathrm{S}$ phase of cell cycle [171]. Apoptosis occurs via caspase-9 and also causes apoptosis in cancer cell lines with mutated p53, suggesting this function is independent of p53 function [172, 173]. Furthermore, Vpr has been reported to increase the expression of TNF- $\alpha$ on dendritic cells and thereby could favor the apoptosis of CD8+ T cells [174]. The Vprmediated depletion of bystander $\mathrm{T}$ cells likely contributes, in part, to immune dysfunction observed in AIDS. Additional mechanism of Vpr mediated T-cell death has been reported. $\mathrm{Vpr}$ alone is sufficient to upregulate NKG2D ligand expression in CD4+ $\mathrm{T}$ lymphocytes, which results in $\mathrm{NK}$ mediated cell death $[175,176]$. Finally $\mathrm{Vpr}$ has also been reported to inhibit the NK activity [174, 177].

$\mathrm{Vpr}$ suppresses the cellular immunity by antigenmediated activation and cytotoxic killing of surviving $\mathrm{T}$ cells. In vivo, it suppresses the Th1 cytokines (IFN-y, IL-12) [162] and promotes the shift toward Th-2 response [178]. $\mathrm{Vpr}$ alters various immunoregulatory molecules at multiple levels in infected $\mathrm{T}$ lymphocytes to escape the host immune response. It downregulates the expression of CD28 and increased the expression of CTLA-4 [179]. CD28 and CTLA-4 are the main costimulatory molecules in T cells that interact with CD80 and CD86 on the antigen presenting cells and initiate the proliferation, differentiation and effector functions. HIV-1 Vpr differentially regulates the expression of cell surface molecules and impaired IFN- $\gamma$ production that is involved in T-cell activation [179]. Vpr has also been shown to suppress the immune activation to superantigens in vivo [180]. Moreover, $\mathrm{Vpr}$ has been shown to modulate NK cell functions, causing a reduction in cytolytic killing and differential regulation of IL-12 and TGF- $\beta$ by smad-3 activation [181]. Therefore, Vpr may significantly contribute to the immune deficiency seen in AIDS by altering both adaptive and innate immune cellular functions.

The effect of Vpr on the immune system seems to be mediated by the interaction with $\mathrm{NF}-\mathrm{KB}$ signaling pathway. $\mathrm{Vpr}$ along with GR have immunosuppressive effects due to $\mathrm{NF}-\mathrm{KB}$ inhibition and induction of $\mathrm{IkB} \alpha$ which prevents the
NF-кB translocation into nucleus thereby preventing cytokine release and immune activation [182, 183]. Vpr induces T-cell apoptosis in a TCR-dependent mechanism by inducing $\mathrm{IKB}$ and inhibiting $\mathrm{NF}-\mathrm{KB}$ activity [184]. $\mathrm{Vpr}$ down-regulates the NF-KB inducible kinase (NIK) and cytokines such as IL-2, IL-12, TNF- $\alpha$, IL-4, MIP-1 $\alpha$, MIP$1 \beta$ and RANTES [184, 185]. Moreover, these effects were reversed with RU486 treatment, suggesting that the inhibition of $\mathrm{NF}-\mathrm{kB}$ via $\mathrm{IkB} \alpha$ involves $\mathrm{GR}$ signaling pathway, indicating the cooperative role of $\mathrm{Vpr}$ and GR in suppressing the NF-KB dependent transcription activity [186]. However, several reports indicate that $\mathrm{Vpr}$ can also activate NF-KB signaling by inducing IKB phosphorylation and subsequent degradation [187-189].

\section{T-CELL SIGNALING AND APOPTOSIS}

\section{T-Cell Apoptosis}

Programmed cell death and necrosis are two main mechanisms by which cells die. Necrosis results from a severe cellular insult and apoptosis is controlled process that occurs without inflammation or injury to surrounding tissue. Deregulation of apoptosis can disrupt the balance between proliferation and cell death [190]. Immune system has its fundamental property to expand rapidly the antigen specific lymphocytes to combat pathogens [191]. The immune response is a multiple step process: naïve $\mathrm{T}$ cells are activated through cross-linking of antigen to TCR, leading to proliferation and differentiation into effector cells. The apoptosis is a crucial step for the termination of acquired immune response and the apoptotic process of elimination of activated $\mathrm{T}$ cells during the termination phase of an immune response is called activation induced cell death (AICD) [192193]. HIV-1 interferes with the death pathway, and HIV-1 players that modulate apoptosis are gp120, Nef, Tat and Vpr [194] (Fig. 2).

\section{Direct Killing of Infected CD4+ T Cells}

Loss of CD4+ $\mathrm{T}$ cells and immune activation are the hallmark of HIV-1 infection. The acute infection is associated with loss of CD4+ T cells and a chronic phase characterized by an immune activation with massive production of proinflammatory cytokines [195, 196] and gradual loss of peripheral CD4+ T cells [197]. During primary infection, before the onset of antiviral immune response, the number of CD4+ $\mathrm{T}$ cells decline in association with high viremia. Moreover, HIV-1 infects preferentially those CD4+ $\mathrm{T}$ cells that are HIV-1 specific and more sensitive to apoptosis $[22,198]$. Loss of infected CD4+ T cells is the result of several mechanisms such as induction of syncytium formation, alteration of membrane permeability, mitochondrial dysfunction, killing by HIV-1 specific cytotoxic $\mathrm{T}$ cells or through the expression of death receptor due to high levels of immune activation [12]. Apoptosis by direct cytopathic effects of HIV-1 occurs via virus induced cytolysis and killing of virus infected cells which occurs via the immune surveillance through the action of cytotoxic $\mathrm{T}$ cells [199, 200]. Syncytia are frequently observed in vitro [201]. Syncytia are generated by the fusion of gp120/gp41 on the plasma membrane of HIV-1 infected cells with uninfected cells bearing a coreceptor, especially CXCR4 [202]. Syncytia are condemned to die by apoptosis due to genomic instability, and p53 seems to play a critical role in 


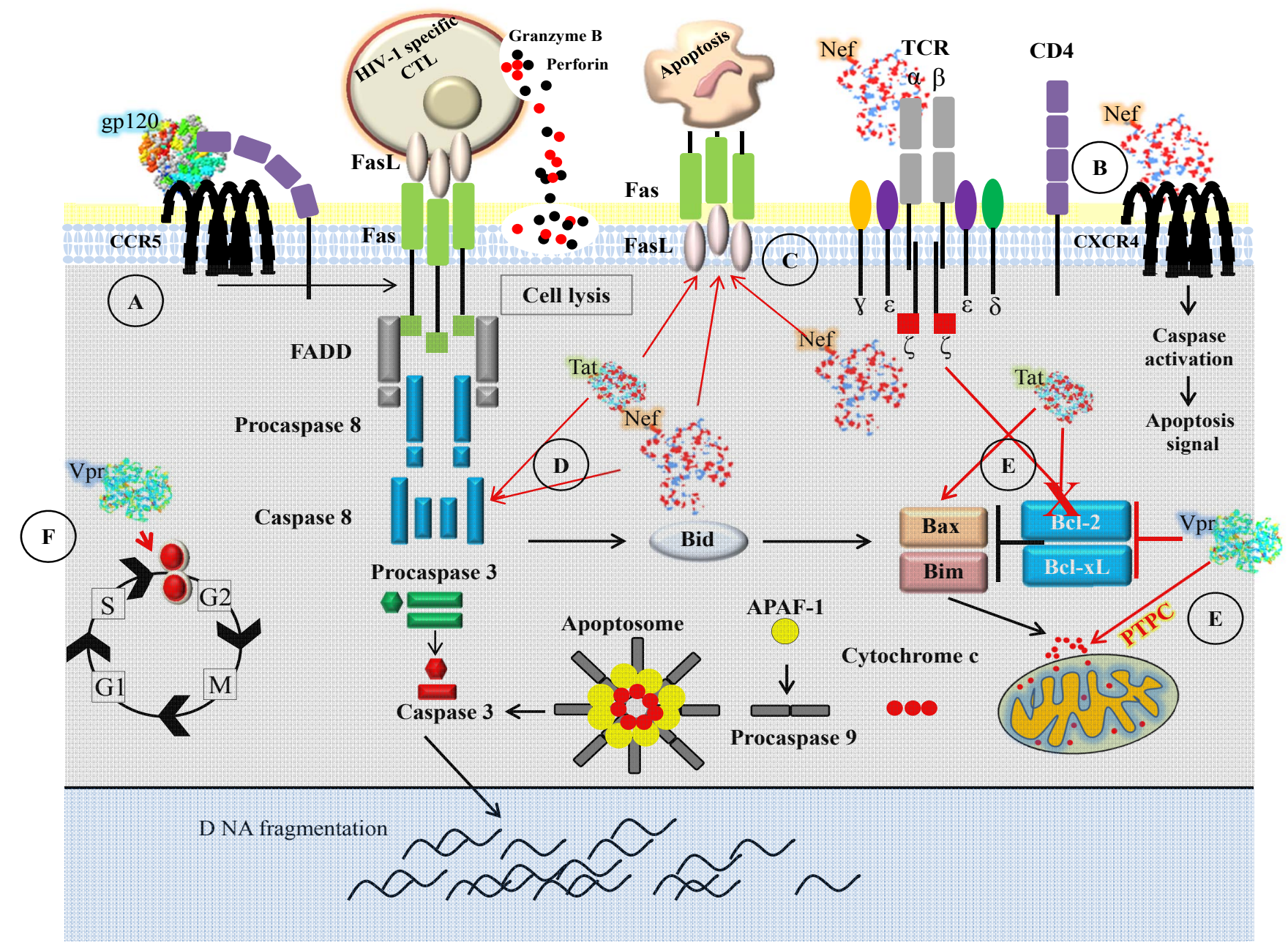

Fig. (2). T-cell death during HIV-1 infection. A) Death associated with gp120 binding to CD4 or CCR5. After binding of gp120 to CD4 or CCR5, it activates intracellular signaling pathways that increase CD4+ T-cell susceptibility to Fas-mediated apoptosis. B) Extracellular Nef interacts with CXCR4 surface receptors and induces apoptosis. C) Nef directly stimulates TCR-CD3 complex and upregulates Fas and FasL expression while also inhibiting the antiapoptotic proteins Bcl-2 family. D) Endogenous Nef and Tat upregulate Fas/FasL and induces apoptosis through caspase-8 pathway. E) Tat and Vpr inhibit Bcl-2 and Bcl-xL, and increase mitochondria dysfunctions. Vpr targets the mitochondrial permeability transition pore complex (PTPC) and causes loss of membrane potential, release of cytochrome c, and the activation of caspase-9 and caspase-3. F) Vpr arrests cells at the G2 phase of the cell cycle that results in apoptosis.

syncytial apoptosis [203]. However, the overall extent of cell-to-cell fusion in vivo has not been estimated [201].

\section{Bystander Immune Activation and Apoptosis}

HIV-1, through the induction of immune activation, generates its own targets for efficient replication. In untreated HIV-1 infection, every arm of immune system is in the state of hyperactivation such as high T-cell turnover, nonspecific T-cell activation and proliferation, polyclonal activation of B-cells and elevated levels of proinflammatory cytokines [204]. A direct contact is required between Env and CXCR4 for the bystander apoptosis of CD4+ T cells. However, soluble secreted factors from CD4+ T cells are required for the bystander apoptosis of CD8+ T cells [205]. Furthermore, it has been reported that the vast majority of bystander T-cell death in lymphoid tissue is due to abortive HIV-1 infection. As naïve CD4+ $\mathrm{T}$ cells are refractory to productive HIV-1 infection, after viral entry, infection is aborted as reverse transcription initiated but fails to reach completion [206, 207]. Accumulation of incomplete reverse transcription in resting CD4+ T cells activates a host defense mechanism that elicits pro-apoptotic and pro-inflammatory responses through caspase- 3 and caspase-1 activation [208]. The death of activated lymphocytes serves to limit the immune response by killing the cells those are no longer needed [193]. These signaling mechanisms depend on the expression of members of TNF/TNFR superfamily such as Fas/FasL and TRAIL/DR5 (Fig. 2) [209, 210]. Naïve T cells express little or no cell surface FasL while its expression increases during T-cell activation and undergo AICD more readily. HIV-1-infected cells are more resistant to apoptosis than uninfected cells [211]. In this way, indirect killing of T cells via Fas/FasL will destroy activated but uninfected cells while sparing the fraction of infected cells.

Bystander $\mathrm{T}$ cells undergo apoptosis upon interaction with HIV-1 infected cells and macrophages plays a major role in this process [212]. HIV-1 infected macrophages expresses apoptosis inducing ligand and induces the 
apoptosis in bystander CD4+ T cells [213]. Furthermore, HIV-1 soluble envelope glycoproteins, resulting from shedding from the surface of viral particles or infected cells, have been implicated as a major cause of bystander cell death in T cells [214]. Cross-linking of cellular receptor CD4 and coreceptor CCR5 with gp120 activates Fas/FasL signaling pathway and induces apoptosis in uninfected CD4+ T cells [215]. Additionally, HIV-1 Nef induces apoptosis in bystander $\mathrm{T}$ cells indirectly via the increased expression of FasL in infected cells [45] or directly by interacting with CXCR4 chemokine receptor [216]. In addition, the secreted form of HIV-1 Tat protein enhances the susceptibility of bystander $\mathrm{T}$ cells to Fas mediated killing $[121,217]$.

The apoptosis of CD8+ $\mathrm{T}$ cells has been widely considered as a strategy used by HIV to evade the immune system [218]. CD8+ T cells eliminate infected cells and HIV-1 specific CD8+ $\mathrm{T}$ cells are highly sensitive to apoptosis [219]. It is apparent that multiple mechanisms that potentially crosstalk are involved in CD8+ T-cell apoptosis during HIV-1 infection [220]. HIV-1 specific CD8+ T cells are highly susceptible to Fas mediated apoptosis, and may affect their ability to deal with HIV-1 infected cells [221]. $\mathrm{CD} 8+\mathrm{T}$ cells are killed by HIV-1 infected macrophages [221]. HIV-1 infected macrophages produce TNF- $\alpha$ in vivo [222]. TNF- $\alpha$ is released as a soluble factor or expressed on the surface of macrophages in a membrane bound form that targets TNFR2 [223, 224]. TNFR-2 stimulation may trigger the apoptosis in CD8+ T cells [223]. Furthermore, TNF- $\alpha$ and TNF receptors increased during HIV-1 infection and inversely correlated with CD4+ T cell counts [225]. In fact, CD8+ T cells apoptosis in HIV-1 infection has been shown to result from interaction of the membrane bound form of TNF- $\alpha$ expressed on the surface of activated macrophages and TNFR-2 expressed on the surface of activated CD8+ T cells [69]. Following CXCR4 stimulation by HIV-1 gp120, both membrane bound TNF- $\alpha$ and TNFR-2 are upregulated on macrophages and CD8+ T cells, respectively [69]. TNFR2 stimulation of $\mathrm{T}$ cells results in decreased intracellular levels of $\mathrm{Bcl}_{-\mathrm{xL}}$, a member of Bcl-2 family. Impaired induction of $\mathrm{Bcl}^{\mathrm{XL}}$ has been observed in PBMCs isolated from HIV-1 infected patients [226].

HIV-1 infection of CD4+ T cells and macrophages results in the upregulation of FasL [30, 227]. The interaction of HIV-1 specific CD8+ T cells in the lymph nodes of patients with HIV-1 infected CD4+ T cells and macrophages could trigger Fas mediated apoptosis of HIV-1 specific CD8+ T cells [228]. Additionally, HIV-1 viral proteins such as Tat and Nef play an important role in bystander apoptosis. It has been demonstrated that Tat and Nef upregulate the expression of FasL and induces the apoptosis in $\mathrm{CD} 8+\mathrm{T}$ cells $[45,229]$.

\section{Thymic Dysfunction Reducing T-Cell Regeneration}

The chronic immune activation during HIV-1 infection indirectly impairs the survival of naïve $T$ cells by damaging the homeostatic mechanisms that maintain the normal populations of naïve $\mathrm{T}$ cells [230]. In the central lymphoid tissue such as thymus, the life of a $\mathrm{T}$ cell begins as a thymic progenitor cell [231]. In the thymus, CD3-CD4-CD8- triple negative thymocytes begins their differentiation and education through multiple interactions between thymocytes and the complex soluble and cellular component of the thymic microenvironment such as self-peptide-MHC-I as well as with IL-7 [232]. Eventually, thymocytes become CD4 or CD8 single positive naïve T cells and are exported to the periphery $[231,232]$.

HIV-1 infection also targets thymus. Examination of thymus in HIV-1 infection reveals a loss of lymphoid cells and a general destruction of thymic architecture [233-234]. HIV-1 replication in thymic microenvironment results in severe disruption of the normal processes of thymopoiesis [235]. Thymic function can be monitored by measuring TCR gene rearrangement excision circles (TREC). A reduction in TREC is observed in HIV-1 infection that reflects HIV induced impairment of thymic function [236]. Furthermore, thymus size is altered in HIV-1 infection and inversely correlated with viral load [237]. These changes in thymus can be partially reversed by antiretroviral therapy [236-238]. Experimental evidence of the infection of thymocytes with HIV has been carried out in thymocytes/TEC suspension culture. Thymocytes in these experimental culture system support high level of HIV-1 infection and replication [239, 240]. Furthermore, similar thymocyte dysfunction was also observed in macaques infected with SIV [241]. HIV-1 infects primarily CD4+ thymocytes in the thymus. However, other cell types such as dendritic cells can also be infected $[233,242]$. Thymic DCs are important for thymopoiesis. These DCs are permissive to HIV-1 infection, resulting in apoptosis, thereby decreasing the number of available thymic DCs for selection which results in altered T-cell development [243]. Additionally, HIV-1 also infects and destroys the stromal cells. This destruction results in an altered thymic architecture that leads to impaired thymopoiesis [244, 245].

Most of HIV-1 replication occurs in the secondary lymphoid tissues, which triggers the chronic immune activation and associated tissue pathologies [246]. The secondary lymphoid tissues are organized to promote immune responses and maintain normal sized populations of $\mathrm{T}$ cells, B cells and antigen presenting cells (APC). T cells encounter antigen presented by antigen presenting cells (APC) in the parafollicular T cell zone, where naïve CD4+ and CD8+ T cells reside and gain excess to IL-7 and other factors required for their survival [247]. In the T cell zone, the fibroblastic reticular cell network (FRCn) gives the essential mechanical support to lymph nodes and is crucial for lymphocyte homeostasis within lymphoid tissues [248]. During the early phase of T-cell depletion by direct killing or other mechanisms such as AICD, the immune activation by HIV-1 elicits a T regulatory response that activates the TGF $\beta$ signaling pathway, thereby triggering the increased production of procollagen and chitinase 3-like-1 (CHI3L1) [18]. The collagen deposition interferes with the physical interaction between IL-7 bearing FRCn and naïve T cells. The survival of naïve $\mathrm{T}$ cell depends on IL-7, therefore, increased apoptosis by loss of access to and source of IL-7 results in depletion of naïve $\mathrm{T}$ cells $[249,250]$.

\section{T-CELL SIGNALING AND FORMATION OF HIV-1 RESERVOIRS}

HIV-1 replicates preferentially in activated CD4+ T cells [251, 252], but these cells generally survive for only few 
days after infection [113]. When a CD4+ T cell encounters with an APC, it starts proliferation and enters into the cell cycle. After series of cell divisions, it gives rise to a clone of activated effector cells. Some of the cells revert back to a quiescent G0 state and persist as memory cells thus allowing rapid responses to future challenges with the same antigen [253]. Interestingly, HIV-1 gene expression is largely silenced as CD4+ T cells undergo in state of memory [254, 255]. Therefore, HIV-1 gene expression is heavily dependent on inducible host transcription factors (NF-KB and NFAT), which are excluded from the nuclei of resting cells [256, 257]. The ultimate result is a stably integrated but transcriptionally silent provirus in a memory $\mathrm{T}$ cells whose function is to survive for a longer period of time. Furthermore, if cells are activated by cytokines or other stimuli, they can start to produce virus. Moreover, in these cells, virus persists as integrated DNA that is unaffected by antiretroviral drugs [58].

Both naïve and resting $\mathrm{CD} 4+\mathrm{T}$ cells provide very restricting environment for HIV-1 replication owing to lowlevel expression of CCR5 and low nucleotide pool and ATP level [258]. The reservoir of latently infected CD4+ T cells having replication competent HIV-1 genomes is established during primary infection [259]. These cells do not progress to complete viral replication unless they are activated [260], and their stability and long half-lives represent a major problem to HIV-1 eradication [261, 262]. It has been proposed that infected memory $\mathrm{T}$ cells can be expanded by homeostatic proliferation driven by IL-7 or low level proliferation driven by antigens [263]. Although resting $\mathrm{CD} 4+\mathrm{T}$ cells or memory $\mathrm{T}$ cells cannot produce viable particles, HIV-1 Nef could increase T-cell activation and therefore facilitate HIV-1 replication in the same cell or in the surrounding cells [264]. After the activation of resting CD4+ $T$ cells, the memory $T$ cells could become infected during decay phase of activation, therefore allowing viral integration with no further progression to active replication [265].

\section{CONCLUSION}

T-cell receptor and signaling molecules are among the tools used by HIV-1 to fuel the progression of the disease. In HIV-1 infection, T-cell signaling events occurred in very well organized and coordinated manner. The survival and persistence of HIV-1 replication is dependent on numerous viral and non-viral factors. A number of T-cell signaling pathways is activated after binding of HIV-1 gp120 to chemokine receptor. These signaling events are very important for productive HIV-1 infection as these signaling pathways ultimately regulates several cellular functions such as cytoskeletal rearrangement, cell survival and differentiation, and activation of several cellular transcription factors. The $\mathrm{T}$ cells are essential in the formation of viral reservoirs and play critical role in HIV-1 disease progression. T-cell activation renders both naïve and memory-resting $\mathrm{T}$ cells susceptible to infection. Several HIV-1 proteins modulate the T-cell signaling in infected and bystander $\mathrm{T}$ cells thereby facilitating disease progression. The infection of resting CD4+ T cells is usually inefficient. To overcome the cellular barriers, HIV relies on its proteins and their binding to cellular partners. Nef and Tat are expressed very early after infection before the integration of
HIV-1 genome and activate transcription factors such as NF$\mathrm{kB}$ that favor cell survival. Then Vpr and Tat activate HIV transcription to complete HIV-1 replicative cycle. At later stages of disease, the combined effect of the viral proteins and perturbation of cytokine signaling fuels HIV-1 pathogenesis. The deleterious effects of immune activation by HIV-1 infection on T-cell signaling and homeostasis could be specifically targeted with new immune-based therapies in addition to standard highly active antiretroviral therapy (HAART). A better understanding of the dynamic interaction between HIV-1 and the host immune system, more specifically T-cell signaling, may lead to the development of vaccine and antiviral strategies that can limit HIV-1 pathogenesis.

\section{CONFLICT OF INTEREST}

GH is the member of the editorial board of the "The Open Virology Journal". The other authors confirm that this article content has no other conflict of interest.

\section{ACKNOWLEDGEMENTS}

This work was supported by grants from the University of Franche-Comté (UFC) and the Région Franche-Comté (RECH-FON12-000013) to G.H. W.A. is a recipient of doctoral scholarship from the Higher Education Commission, Pakistan. We thank Diasorin SA for its financial support.

\section{REFERENCES}

[1] Derdeyn CA, Silvestri G. Viral and host factors in the pathogenesis of HIV infection. Curr Opin Immunol 2005; 17(4): 366-73.

[2] Cummins NW, Badley AD. Mechanisms of HIV-associated lymphocyte apoptosis 2010; Cell Death Dis 2010; 1: e99.

[3] Douek DC, Roederer M, Koup RA. Emerging concepts in the immunopathogenesis of AIDS. Annu Rev Med 2009; 60: 471-84.

[4] Saha K, Firdaus R, Santra P, et al. Recent pattern of Co-infection amongst HIV seropositive individuals in tertiary care hospital, Kolkata. Virol J 2011; 8: 116.

[5] Herbein G, Varin A. The macrophage in HIV-1 infection: from activation to deactivation? Retrovirology 2010; 7: 33 .

[6] McMichael AJ, Borrow P, Tomaras GD, Goonetilleke N, Haynes BF. The immune response during acute HIV-1 infection: clues for vaccine development. Nat Rev Immunol 2010; 10(1): 11-23.

[7] Blanchet FP, Moris A, Nikolic DS, et al. Human immunodeficiency virus-1 inhibition of immunoamphisomes in dendritic cells impairs early innate and adaptive immune responses. Immunity 2010; 32(5): 654-69.

[8] Wu L, KewalRamani VN. Dendritic-cell interactions with HIV: infection and viral dissemination. Nat Rev Immunol 2006; 6(11): 859-68.

[9] Puryear WB, Akiyama H, Geer SD, et al. Interferon-inducible mechanism of dendritic cell-mediated HIV-1 dissemination is dependent on Siglec-1/CD169. PLoS Pathog 2013; 9(4): e1003291.

[10] Izquierdo-Useros N, Lorizate M, Puertas MC, et al. Siglec-1 is a novel dendritic cell receptor that mediates HIV-1 trans-infection through recognition of viral membrane gangliosides. PLoS Biol 2012; 10(12): e1001448.

[11] Haase AT. Targeting early infection to prevent HIV-1 mucosal transmission. Nature 2010; 464(7286): 217-23.

[12] Mattapallil JJ, Douek DC, Hill B, Nishimura Y, Martin M, Roederer M. Massive infection and loss of memory CD4+ T cells in multiple tissues during acute SIV infection. Nature 2005; 434(7037): 1093-7.

[13] Li Q, Duan L, Estes JD, et al. Peak SIV replication in resting memory CD4+ $\mathrm{T}$ cells depletes gut lamina propria CD4+ T cells. Nature 2005; 434(7037): 1148-52.

[14] Kahn JO, Walker BD. Acute human immunodeficiency virus type 1 infection. N Engl J Med 1998; 339(1): 33-9.

[15] Dinoso JB, Kim SY, Wiegand AM, et al. Treatment intensification does not reduce residual HIV-1 viremia in patients on highly active 
antiretroviral therapy. Proc Natl Acad Sci USA 2009; 106(23): 9403-8.

[16] Brenchley JM, Price DA, Schacker TW, et al. Microbial translocation is a cause of systemic immune activation in chronic HIV infection. Nat Med 2006; 12(12): 1365-71.

[17] Grossman Z, Meier-Schellersheim M, Paul WE, Picker LJ. Pathogenesis of HIV infection: what the virus spares is as important as what it destroys. Nat Med 2006; 12(3): 289-95.

[18] Estes JD, Wietgrefe S, Schacker T, et al. Simian immunodeficiency virus-induced lymphatic tissue fibrosis is mediated by transforming growth factor beta 1-positive regulatory $\mathrm{T}$ cells and begins in early infection. J Infect Dis 2007; 195(4): 551-61.

[19] McCune JM. The dynamics of CD4+ T-cell depletion in HIV disease. Nature 2001; 410(6831): 974-9.

[20] Hellerstein MK, Hoh RA, Hanley MB, et al. Subpopulations of long-lived and short-lived $\mathrm{T}$ cells in advanced HIV-1 infection. J Clin Invest 2003; 112(6): 956-66.

[21] Hazenberg MD, Stuart JW, Otto SA, et al. T-cell division in human immunodeficiency virus (HIV)-1 infection is mainly due to immune activation: a longitudinal analysis in patients before and during highly active antiretroviral therapy (HAART). Blood 2000; 95(1): 249-55.

[22] Yue FY, Kovacs CM, Dimayuga RC, et al. Preferential apoptosis of HIV-1-specific CD4+ T cells. J Immunol 2005; 174(4): 2196204.

[23] Wu Y, Marsh JW. Selective transcription and modulation of resting T cell activity by preintegrated HIV DNA. Science 2001; 293(5534): 1503-6.

[24] Geyer M, Peterlin BM. Domain assembly, surface accessibility and sequence conservation in full length HIV-1 Nef. FEBS Lett 2001; 496(2-3): 91-5.

[25] Arold ST, Baur AS. Dynamic Nef and Nef dynamics: how structure could explain the complex activities of this small HIV protein. Trends Biochem Sci 2001; 26(6): 356-63.

[26] Garcia JV, Miller AD. Serine phosphorylation-independent downregulation of cell-surface CD4 by nef. Nature 1991; 350(6318): 508-11.

[27] Swigut T, Shohdy N, Skowronski J. Mechanism for downregulation of CD28 by Nef. EMBO J 2001; 20(7): 1593-604.

[28] Swigut T, Greenberg M, Skowronski J. Cooperative interactions of simian immunodeficiency virus Nef, AP-2, and CD3-zeta mediate the selective induction of T-cell receptor-CD3 endocytosis. J Virol 2003; 77(14): 8116-26.

[29] Schwartz O, Marechal V, Le Gall S, Lemonnier F, Heard JM. Endocytosis of major histocompatibility complex class I molecules is induced by the HIV-1 Nef protein. Nat Med 1996; 2(3): 338-42.

[30] $\mathrm{Xu}$ XN, Screaton GR, Gotch FM, et al. Evasion of cytotoxic T lymphocyte (CTL) responses by nef-dependent induction of Fas ligand (CD95L) expression on simian immunodeficiency virusinfected cells. J Exp Med 1997; 186(1): 7-16.

[31] Collins KL, Chen BK, Kalams SA, Walker BD, Baltimore D. HIV1 Nef protein protects infected primary cells against killing by cytotoxic T lymphocytes. Nature 1998; 391(6665): 397-401.

[32] Xu XN, Screaton GR, McMichael AJ. Virus infections: escape, resistance, and counterattack. Immunity 2001; 15(6): 867-70.

[33] Fujii Y, Otake K, Tashiro M, Adachi A. Soluble Nef antigen of HIV-1 is cytotoxic for human CD4+ T cells. FEBS Lett 1996; 393(1): 93-6.

[34] Kuster H, Opravil M, Ott P, et al. Treatment-induced decline of human immunodeficiency virus-1 p24 and HIV-1 RNA in lymphoid tissue of patients with early human immunodeficiency virus-1 infection. Am J Pathol 2000; 156(6): 1973-86.

[35] Soudeyns H, Rebai N, Pantaleo GP, et al. The T cell receptor V beta repertoire in HIV-1 infection and disease. Semin Immunol 1993; 5(3): 175-85.

[36] Olivetta E, Percario Z, Fiorucci G, et al. HIV-1 Nef induces the release of inflammatory factors from human monocyte/macrophages: involvement of Nef endocytotic signals and NF-kappa B activation. J Immunol 2003; 170(4): 1716-27.

[37] Baur AS, Sawai ET, Dazin P, Fantl WJ, Cheng-Mayer C, Peterlin BM. HIV-1 Nef leads to inhibition or activation of $\mathrm{T}$ cells depending on its intracellular localization. Immunity 1994; 1(5): 373-84.

[38] Hanna Z, Kay DG, Rebai N, Guimond A, Jothy S, Jolicoeur P. Nef harbors a major determinant of pathogenicity for an AIDS-like disease induced by HIV-1 in transgenic mice. Cell 1998; 95(2): 163-75.

[39] Luo W, Peterlin BM. Activation of the T-cell receptor signaling pathway by Nef from an aggressive strain of simian immunodeficiency virus. J Virol 1997; 71(12): 9531-7.

[40] Wang JK, Kiyokawa E, Verdin E, Trono D. The Nef protein of HIV-1 associates with rafts and primes T cells for activation. Proc Nat Acad Sci USA 2000; 97(1): 394-9.

[41] Fenard D, Yonemoto W, de Noronha C, Cavrois M, Williams SA, Greene WC. Nef is physically recruited into the immunological synapse and potentiates $\mathrm{T}$ cell activation early after TCR engagement. J Immunol 2005; 175(9): 6050-7.

[42] Simmons A, Aluvihare V, McMichael A. Nef triggers a transcriptional program in $\mathrm{T}$ cells imitating single-signal $\mathrm{T}$ cell activation and inducing HIV virulence mediators. Immunity 2001; 14(6): 763-77.

[43] Neri F, Giolo G, Potesta M, Petrini S, Doria M. The HIV-1 Nef protein has a dual role in $\mathrm{T}$ cell receptor signaling in infected CD4+ T lymphocytes. Virology 2011; 410(2): 316-26.

[44] Fackler OT, Baur AS. Live and let die: Nef functions beyond HIV replication. Immunity 2002; 16(4): 493-7.

[45] $\mathrm{Xu} \mathrm{XN,} \mathrm{Laffert} \mathrm{B,} \mathrm{Screaton} \mathrm{GR,} \mathrm{et} \mathrm{al.} \mathrm{Induction} \mathrm{of} \mathrm{Fas} \mathrm{ligand}$ expression by HIV involves the interaction of Nef with the T cell receptor zeta chain. J Exp Med 1999; 189(9): 1489-96.

[46] Fackler OT, Luo W, Geyer M, Alberts AS, Peterlin BM. Activation of Vav by Nef induces cytoskeletal rearrangements and downstream effector functions. Mol Cell 1999; 3(6): 729-39.

[47] Baur AS, Sass G, Laffert B, Willbold D, Cheng-Mayer C, Peterlin BM. The N-terminus of Nef from HIV-1/SIV associates with a protein complex containing Lck and a serine kinase. Immunity 1997; 6(3): 283-91.

[48] Sawai ET, Baur A, Struble H, Peterlin BM, Levy JA, Cheng-Mayer C. Human immunodeficiency virus type 1 Nef associates with a cellular serine kinase in T lymphocytes. Proc Nat Acad Sci USA 1994; 91(4): 1539-43.

[49] Smith BL, Krushelnycky BW, Mochly-Rosen D, Berg P. The HIV nef protein associates with protein kinase $\mathrm{C}$ theta. J Biol Chem 1996; 271(28): 16753-7.

[50] Janardhan A, Swigut T, Hill B, Myers MP, Skowronski J. HIV-1 Nef binds the DOCK2-ELMO1 complex to activate rac and inhibit lymphocyte chemotaxis. PLoS Biol 2004; 2(1): E6.

[51] Schrager JA, Der Minassian V, Marsh JW. HIV Nef increases T cell ERK MAP kinase activity. J Biol Chem 2002; 277(8): 613742.

[52] Saksela K, Cheng G, Baltimore D. Proline-rich (PxxP) motifs in HIV-1 Nef bind to SH3 domains of a subset of Src kinases and are required for the enhanced growth of Nef+ viruses but not for downregulation of CD4. EMBO J 1995; 14(3): 484-91.

[53] Briggs SD, Sharkey M, Stevenson M, Smithgall TE. SH3-mediated Hck tyrosine kinase activation and fibroblast transformation by the Nef protein of HIV-1. J Biol Chem 1997; 272(29): 17899-902.

[54] Howe AY, Jung JU, Desrosiers RC. Zeta chain of the T-cell receptor interacts with nef of simian immunodeficiency virus and human immunodeficiency virus type 2. J Virol 1998; 72(12): 982734.

[55] Fackler OT, Lu X, Frost JA, et al. p21-activated kinase 1 plays a critical role in cellular activation by Nef. Mol Cell Biol 2000; 20(7): 2619-27.

[56] Renkema GH, Manninen A, Mann DA, Harris M, Saksela K. Identification of the Nef-associated kinase as p21-activated kinase 2. Curr Biol 1999; 9(23): 1407-10.

[57] Zack JA, Arrigo SJ, Weitsman SR, Go AS, Haislip A, Chen IS. HIV-1 entry into quiescent primary lymphocytes: molecular analysis reveals a labile, latent viral structure. Cell 1990; 61(2): 213-22.

[58] Abbas W, Herbein G. Molecular Understanding of HIV-1 Latency. Adv Virol 2012; 2012: 574967.

[59] Stevenson M. HIV-1 pathogenesis. Nat Med 2003; 9(7): 853-60.

[60] Kinoshita S, Chen BK, Kaneshima H, Nolan GP. Host control of HIV-1 parasitism in $\mathrm{T}$ cells by the nuclear factor of activated $\mathrm{T}$ cells. Cell 1998; 95(5): 595-604.

[61] Keppler OT, Tibroni N, Venzke S, Rauch S, Fackler OT Modulation of specific surface receptors and activation sensitization in primary resting CD4+ T lymphocytes by the Nef protein of HIV-1. J Leukoc Biol 2006; 79(3): 616-27. 
[62] Petit C, Buseyne F, Boccaccio C, Abastado JP, Heard JM, Schwartz O. Nef is required for efficient HIV-1 replication in cocultures of dendritic cells and lymphocytes. Virology 2001; 286(1): 225-36.

[63] Fackler OT, Wolf D, Weber HO, et al. A natural variability in the proline-rich motif of Nef modulates HIV-1 replication in primary T cells. Curr Biol 2001; 11(16): 1294-9.

[64] Herbein G, Gras G, Khan KA, Abbas W. Macrophage signaling in HIV-1 infection. Retrovirology 2010; 7: 34.

[65] Swingler S, Mann A, Jacque J, et al. HIV-1 Nef mediates lymphocyte chemotaxis and activation by infected macrophages. Nat Med 1999; 5(9): 997-103.

[66] Sol-Foulon N, Moris A, Nobile C, et al. HIV-1 Nef-induced upregulation of DC-SIGN in dendritic cells promotes lymphocyte clustering and viral spread. Immunity 2002; 16(1): 145-55.

[67] Benedict CA, Norris PS, Ware CF. To kill or be killed: viral evasion of apoptosis. Nat Immunol 2002; 3(11): 1013-8.

[68] Herbein G, Khan KA. Is HIV infection a TNF receptor signallingdriven disease? Trends Immunol 2008; 29(2): 61-7.

[69] Herbein G, Mahlknecht U, Batliwalla F, et al. Apoptosis of CD8+ $\mathrm{T}$ cells is mediated by macrophages through interaction of HIV gp120 with chemokine receptor CXCR4. Nature 1998; 395(6698): $189-94$.

[70] Geleziunas R, Xu W, Takeda K, Ichijo H, Greene WC. HIV-1 Nef inhibits ASK1-dependent death signalling providing a potential mechanism for protecting the infected host cell. Nature 2001; 410(6830): 834-8.

[71] Hattori K, Naguro I, Runchel C, Ichijo H. The roles of ASK family proteins in stress responses and diseases. Cell Commun Signal 2009; 7: 9.

[72] Wolf D, Witte V, Laffert B, et al. HIV-1 Nef associated PAK and PI3-kinases stimulate Akt-independent Bad-phosphorylation to induce anti-apoptotic signals. Nat Med 2001; 7(11): 1217-24.

[73] Yoon V, Fridkis-Hareli M, Munisamy S, Lee J, Anastasiades D, Stevceva L. The GP120 molecule of HIV-1 and its interaction with T cells. Curr Med Chem 2010; 17(8): 741-9.

[74] Santosuosso M, Righi E, Lindstrom V, Leblanc PR, Poznansky MC. HIV-1 envelope protein gp120 is present at high concentrations in secondary lymphoid organs of individuals with chronic HIV-1 infection. J Infect Dis 2009; 200(7): 1050-3.

[75] Santosuosso M, Righi E, Hill ED, et al. R5-SHIV induces multiple defects in $\mathrm{T}$ cell function during early infection of rhesus macaques including accumulation of $\mathrm{T}$ reg cells in lymph nodes. PloS ONE 2011; 6(4): e 18465.

[76] Chougnet C, Gessani S. Role of gp120 in dendritic cell dysfunction in HIV infection. J Leukoc Biol 2006; 80(5): 994-1000.

[77] Wu Y, Yoder A. Chemokine coreceptor signaling in HIV-1 infection and pathogenesis. PLoS Pathog 2009; 5(12): e1000520.

[78] Choe H, Farzan M, Sun Y, et al. The beta-chemokine receptors CCR3 and CCR5 facilitate infection by primary HIV-1 isolates. Cell 1996; 85(7): 1135-48.

[79] Connor RI, Sheridan KE, Ceradini D, Choe S, Landau NR. Change in coreceptor use correlates with disease progression in HIV-1-infected individuals. J Exp Med 1997; 185(4): 621-8.

[80] Davis CB, Dikic I, Unutmaz D, et al. Signal transduction due to HIV-1 envelope interactions with chemokine receptors CXCR4 or CCR5. J Exp Med 1997; 186(10): 1793-8.

[81] Lev S, Moreno H, Martinez R, et al. Protein tyrosine kinase PYK2 involved in $\mathrm{Ca}(2+)$-induced regulation of ion channel and MAP kinase functions. Nature 1995; 376(6543): 737-45.

[82] Francois F, Klotman ME. Phosphatidylinositol 3-kinase regulates human immunodeficiency virus type 1 replication following viral entry in primary CD4+ T lymphocytes and macrophages. J Virol 2003; 77(4): 2539-49.

[83] Balabanian K, Harriague J, Decrion C, et al. CXCR4-tropic HIV-1 envelope glycoprotein functions as a viral chemokine in unstimulated primary CD4+ T lymphocytes. J Immunol 2004; 173(12): 7150-60.

[84] Cicala C, Arthos J, Censoplano N, et al. HIV-1 gp120 induces NFAT nuclear translocation in resting CD4+ T-cells. Virology 2006; 345(1): 105-14

[85] Kinter AL, Umscheid CA, Arthos J, et al. HIV envelope induces virus expression from resting CD4+ $\mathrm{T}$ cells isolated from HIVinfected individuals in the absence of markers of cellular activation or apoptosis. J Immunol 2003; 170(5): 2449-55.
[86] Arthos J, Rubbert A, Rabin RL, et al. CCR5 signal transduction in macrophages by human immunodeficiency virus and simian immunodeficiency virus envelopes. J Virol 2000; 74(14): 6418-24.

[87] Chackerian B, Long EM, Luciw PA, Overbaugh J. Human immunodeficiency virus type 1 coreceptors participate in postentry stages in the virus replication cycle and function in simian immunodeficiency virus infection. J Virol 1997; 71(5): 3932-9.

[88] Samstag Y, Eibert SM, Klemke M, Wabnitz GH. Actin cytoskeletal dynamics in T lymphocyte activation and migration. J Leukoc Biol 2003; 73(1): 30-48.

[89] Nishita M, Aizawa H, Mizuno K. Stromal cell-derived factor 1alpha activates LIM kinase 1 and induces cofilin phosphorylation for T-cell chemotaxis. Mol Cell Biol 2002; 22(3): 774-83.

[90] Eibert SM, Lee KH, Pipkorn R, et al. Cofilin peptide homologs interfere with immunological synapse formation and $\mathrm{T}$ cell activation. Proc Natl Acad Sci USA 2004; 101(7): 1957-62.

[91] Yoder A, Yu D, Dong L, et al. HIV envelope-CXCR4 signaling activates cofilin to overcome cortical actin restriction in resting CD4 T cells. Cell 2008; 134(5): 782-92.

[92] Stevceva L, Yoon V, Carville A, et al. The efficacy of T cellmediated immune responses is reduced by the envelope protein of the chimeric HIV-1/SIV-KB9 virus in vivo. J Immunol 2008; 181(8): 5510-21.

[93] Shan M, Klasse PJ, Banerjee K, et al. HIV-1 gp120 mannoses induce immunosuppressive responses from dendritic cells. PLoS pathogens 2007; 3(11): e169.

[94] Banerjee K, Andjelic S, Klasse PJ, et al. Enzymatic removal of mannose moieties can increase the immune response to HIV-1 gp120 in vivo. Virology 2009; 389(1-2): 108-21.

[95] Jeang KT, Xiao H, Rich EA. Multifaceted activities of the HIV-1 transactivator of transcription, Tat. J Biol Chem 1999; 274(41): 28837-40.

[96] Schwartz S, Felber BK, Fenyo EM, Pavlakis GN. Env and Vpu proteins of human immunodeficiency virus type 1 are produced from multiple bicistronic mRNAs. J Virol 1990; 64(11): 5448-56.

[97] Mahlknecht U, Dichamp I, Varin A, Van Lint C, Herbein G. NFkappaB-dependent control of HIV-1 transcription by the second coding exon of Tat in T cells. J Leukoc Biol 2008; 83(3): 718-27.

[98] Green M, Ishino M, Loewenstein PM. Mutational analysis of HIV1 Tat minimal domain peptides: identification of trans-dominant mutants that suppress HIV-LTR-driven gene expression. Cell 1989; 58(1): 215-23.

[99] Ensoli B, Buonaguro L, Barillari G, et al. Release, uptake, and effects of extracellular human immunodeficiency virus type 1 Tat protein on cell growth and viral transactivation. J Virol 1993; 67(1): 277-87.

[100] Ensoli B, Barillari G, Salahuddin SZ, Gallo RC, Wong-Staal F. Tat protein of HIV-1 stimulates growth of cells derived from Kaposi's sarcoma lesions of AIDS patients. Nature 1990; 345(6270): 84-6.

[101] Vogel BE, Lee SJ, Hildebrand A, et al. A novel integrin specificity exemplified by binding of the alpha $\mathrm{v}$ beta 5 integrin to the basic domain of the HIV Tat protein and vitronectin. J Cell Biol 1993; 121(2): 461-8.

[102] Hakansson S, Jacobs A, Caffrey M. Heparin binding by the HIV-1 tat protein transduction domain. Protein Sci 2001; 10(10): 2138-9.

[103] Albini A, Ferrini S, Benelli R, et al. HIV-1 Tat protein mimicry of chemokines. Proc Natl Acad Sci USA 1998; 95(22): 13153-8.

[104] Ammosova T, Berro R, Jerebtsova M, et al. Phosphorylation of HIV-1 Tat by CDK2 in HIV-1 transcription. Retrovirology 2006; 3 : 78 .

[105] Deng L, Ammosova T, Pumfery A, Kashanchi F, Nekhai S. HIV-1 Tat interaction with RNA polymerase II C-terminal domain (CTD) and a dynamic association with CDK2 induce CTD phosphorylation and transcription from HIV-1 promoter. J Biol Chem 2002; 277(37): 33922-9.

[106] Li JC, Lee DC, Cheung BK, Lau AS. Mechanisms for HIV Tat upregulation of IL-10 and other cytokine expression: kinase signaling and PKR-mediated immune response. FEBS Lett 2005; 579(14): 3055-62.

[107] Gupta S, Boppana R, Mishra GC, Saha B, Mitra D. HIV-1 Tat suppresses gp120-specific $\mathrm{T}$ cell response in IL-10-dependent manner. J Immunol 2008; 180(1): 79-88.

[108] Clerici M, Wynn TA, Berzofsky JA, et al. Role of interleukin-10 in $\mathrm{T}$ helper cell dysfunction in asymptomatic individuals infected with the human immunodeficiency virus. J Clin Invest 1994; 93(2): 76875 . 
[109] Saraiva M, O'Garra A. The regulation of IL-10 production by immune cells. Nat Rev Immunol 2010; 10(3): 170-81.

[110] Ouyang W, Rutz S, Crellin NK, Valdez PA, Hymowitz SG. Regulation and functions of the IL-10 family of cytokines in inflammation and disease. Annu Rev Immunol 2011; 29: 71-109.

[111] Huang L, Bosch I, Hofmann W, Sodroski J, Pardee AB. Tat protein induces human immunodeficiency virus type 1 (HIV-1) coreceptors and promotes infection with both macrophage-tropic and Tlymphotropic HIV-1 strains. J Virol 1998; 72(11): 8952-60.

[112] Li CJ, Ueda Y, Shi B, et al. Tat protein induces self-perpetuating permissivity for productive HIV-1 infection. Proc Natl Acad Sci USA 1997; 94(15): 8116-20.

[113] Ho DD, Neumann AU, Perelson AS, Chen W, Leonard JM, Markowitz M. Rapid turnover of plasma virions and CD4 lymphocytes in HIV-1 infection. Nature 1995; 373(6510): 123-6.

[114] Wei X, Ghosh SK, Taylor ME, et al. Viral dynamics in human immunodeficiency virus type 1 infection. Nature 1995; 373(6510): 117-22.

[115] Faller EM, Sugden SM, McVey MJ, Kakal JA, MacPherson PA. Soluble HIV Tat protein removes the IL-7 receptor alpha-chain from the surface of resting CD8 $\mathrm{T}$ cells and targets it for degradation. J Immunol 2010; 185(5): 2854-66.

[116] Mackall CL, Fry TJ, Gress RE. Harnessing the biology of IL-7 for therapeutic application. Nat Rev Immunol 2011; 11(5): 330-42.

[117] Colle JH, Moreau JL, Fontanet A, et al. CD127 expression and regulation are altered in the memory CD8 $\mathrm{T}$ cells of HIV-infected patients--reversal by highly active anti-retroviral therapy (HAART). Clin Exp Immunol 2006; 143(3): 398-403.

[118] MacPherson PA, Fex C, Sanchez-Dardon J, Hawley-Foss N, Angel JB. Interleukin-7 receptor expression on CD8(+) T cells is reduced in HIV infection and partially restored with effective antiretroviral therapy. J Acquir Immune Defic Syndr 2001; 28(5): 454-7.

[119] Vassena L, Miao H, Cimbro R, et al. Treatment with IL-7 prevents the decline of circulating CD4+ T cells during the acute phase of SIV infection in rhesus macaques. PLoS Pathog 2012; 8(4): e1002636.

[120] Ott M, Emiliani S, Van Lint C, et al. Immune hyperactivation of HIV-1-infected $\mathrm{T}$ cells mediated by Tat and the CD28 pathway. Science 1997; 275(5305): 1481-5

[121] Li CJ, Friedman DJ, Wang C, Metelev V, Pardee AB. Induction of apoptosis in uninfected lymphocytes by HIV-1 Tat protein. Science 1995; 268(5209): 429-31.

[122] Matsui M, Warburton RJ, Cogswell PC, Baldwin AS, Jr., Frelinger JA. Effects of HIV-1 Tat on expression of HLA class I molecules. J Acquir Immune Defic Syndr Hum Retrovirol 1996; 11(3): 233-40.

[123] Campbell GR, Pasquier E, Watkins J, et al. The glutamine-rich region of the HIV-1 Tat protein is involved in T-cell apoptosis. J Biol Chem 2004; 279(46): 48197-204.

[124] Aries SP, Schaaf B, Muller C, Dennin RH, Dalhoff K. Fas (CD95) expression on CD4+ T cells from HIV-infected patients increases with disease progression. J Mol Med 1995; 73(12): 591-3.

[125] Campbell GR, Watkins JD, Esquieu D, Pasquier E, Loret EP, Spector SA. The $\mathrm{C}$ terminus of HIV-1 Tat modulates the extent of CD178-mediated apoptosis of T cells. J Biol Chem 2005; 280(46): 38376-82.

[126] Kim N, Kukkonen S, Gupta S, Aldovini A. Association of Tat with promoters of PTEN and PP2A subunits is key to transcriptional activation of apoptotic pathways in HIV-infected CD4+ T cells. PLoS Pathog 2010; 6(9): e1001103.

[127] Barillari G, Buonaguro L, Fiorelli V, et al. Effects of cytokines from activated immune cells on vascular cell growth and HIV-1 gene expression. Implications for AIDS-Kaposi's sarcoma pathogenesis. J Immunol 1992; 149(11): 3727-34.

[128] Poli G, Kinter A, Justement JS, et al. Tumor necrosis factor alpha functions in an autocrine manner in the induction of human immunodeficiency virus expression. Proc Natl Acad Sci USA 1990; 87(2): 782-5.

[129] Scala G, Ruocco MR, Ambrosino C, et al. The expression of the interleukin 6 gene is induced by the human immunodeficiency virus 1 TAT protein. J Exp Med 1994; 179(3): 961-71.

[130] Buonaguro L, Barillari G, Chang HK, et al. Effects of the human immunodeficiency virus type 1 Tat protein on the expression of inflammatory cytokines. J Virol 1992; 66(12): 7159-67.

[131] Kono T, Minami Y, Taniguchi T. The interleukin-2 receptor complex and signal transduction: role of the beta-chain. Semin Immunol 1993; 5(5): 299-307.
[132] Westendorp MO, Li-Weber M, Frank RW, Krammer PH. Human immunodeficiency virus type 1 Tat upregulates interleukin-2 secretion in activated T cells. J Virol 1994; 68(7): 4177-85.

[133] Cohen EA, Dehni G, Sodroski JG, Haseltine WA. Human immunodeficiency virus vpr product is a virion-associated regulatory protein. J Virol 1990; 64(6): 3097-9.

[134] Yuan X, Matsuda Z, Matsuda M, Essex M, Lee TH. Human immunodeficiency virus vpr gene encodes a virion-associated protein. AIDS Res Hum Retroviruses 1990; 6(11): 1265-71.

[135] Tristem M, Marshall C, Karpas A, Hill F. Evolution of the primate lentiviruses: evidence from vpx and vpr. EMBO J 1992; 11(9): 3405-12.

[136] Romani B, Engelbrecht S. Human immunodeficiency virus type 1 Vpr: functions and molecular interactions. J Gen Virol 2009; 90(Pt 8): 1795-805.

[137] Kogan M, Deshmane S, Sawaya BE, Gracely EJ, Khalili K, Rappaport J. Inhibition of NF-kappaB activity by HIV-1 Vpr is dependent on Vpr binding protein. J Cell Physiol 2013; 228(4): 781-90.

[138] Trono D. HIV accessory proteins: leading roles for the supporting cast. Cell 1995; 82(2): 189-92.

[139] Cohen EA, Terwilliger EF, Jalinoos Y, Proulx J, Sodroski JG, Haseltine WA. Identification of HIV-1 vpr product and function. J Acquir Immune Defic Syndr 1990; 3(1): 11-8.

[140] Piller SC, Ewart GD, Premkumar A, Cox GB, Gage PW. Vpr protein of human immunodeficiency virus type 1 forms cationselective channels in planar lipid bilayers. Proc Natl Acad Sci USA 1996; 93(1): 111-5.

[141] Levy DN, Refaeli Y, MacGregor RR, Weiner DB. Serum Vpr regulates productive infection and latency of human immunodeficiency virus type 1. Proc Natl Acad Sci USA 1994; 91(23): 10873-7.

[142] Levy DN, Refaeli Y, Weiner DB. Extracellular Vpr protein increases cellular permissiveness to human immunodeficiency virus replication and reactivates virus from latency. J Virol 1995; 69(2): 1243-52.

[143] Agostini I, Navarro JM, Rey F, et al. The human immunodeficiency virus type $1 \mathrm{Vpr}$ transactivator: cooperation with promoter-bound activator domains and binding to TFIIB. J Mol Biol 1996; 261(5): 599-606.

[144] Wang L, Mukherjee S, Jia F, Narayan O, Zhao LJ. Interaction of virion protein $\mathrm{Vpr}$ of human immunodeficiency virus type 1 with cellular transcription factor Sp1 and trans-activation of viral long terminal repeat. J Biol Chem 1995; 270(43): 25564-9.

[145] Ghosh D. Glucocorticoid receptor-binding site in the human immunodeficiency virus long terminal repeat. J Virol 1992; 66(1): 586-90.

[146] McAllister JJ, Phillips D, Millhouse S, et al. Analysis of the HIV-1 LTR NF-kappaB-proximal Sp site III: evidence for cell typespecific gene regulation and viral replication. Virology 2000; 274(2): 262-77.

[147] Verhoef K, Sanders RW, Fontaine V, Kitajima S, Berkhout B. Evolution of the human immunodeficiency virus type 1 long terminal repeat promoter by conversion of an NF-kappaB enhancer element into a GABP binding site. J Virol 1999; 73(2): 1331-40.

[148] Ishii S, Kadonaga JT, Tjian R, Brady JN, Merlino GT, Pastan I. Binding of the Sp1 transcription factor by the human Harvey ras 1 proto-oncogene promoter. Science 1986; 232(4756): 1410-3.

[149] Meeker TC, Loeb J, Ayres M, Sellers W. The human Pim-1 gene is selectively transcribed in different hemato-lymphoid cell lines in spite of a G + C-rich housekeeping promoter. Mol Cell Biol 1990; 10(4): 1680-8.

[150] Vanitharani R, Mahalingam S, Rafaeli Y, et al. HIV-1 Vpr transactivates LTR-directed expression through sequences present within -278 to -176 and increases virus replication in vitro. Virology 2001; 289(2): 334-42.

[151] Felzien LK, Woffendin C, Hottiger MO, Subbramanian RA, Cohen EA, Nabel GJ. HIV transcriptional activation by the accessory protein, VPR, is mediated by the p300 co-activator. Proc Natl Acad Sci USA 1998; 95(9): 5281-6.

[152] Kino T, Tsukamoto M, Chrousos G. Transcription factor TFIIH components enhance the GR coactivator activity but not the cell cycle-arresting activity of the human immunodeficiency virus type1 protein Vpr. Biochem Biophys Res Commun 2002; 298(1): 1723. 
[153] Sawaya BE, Khalili K, Rappaport J, et al. Suppression of HIV-1 transcription and replication by a Vpr mutant. Gene Ther 1999; 6(5): 947-50.

[154] Kino T, Gragerov A, Slobodskaya O, Tsopanomichalou M, Chrousos GP, Pavlakis GN. Human immunodeficiency virus type 1 (HIV-1) accessory protein $\mathrm{Vpr}$ induces transcription of the HIV-1 and glucocorticoid-responsive promoters by binding directly to p300/CBP coactivators. J Virol 2002; 76(19): 9724-34.

[155] Rosenberg ES, Billingsley JM, Caliendo AM, et al. Vigorous HIV1-specific CD4+ $\mathrm{T}$ cell responses associated with control of viremia. Science 1997; 278(5342): 1447-50.

[156] Stevenson PG, Bangham CR, Hawke S. Recruitment, activation and proliferation of CD8+ memory $\mathrm{T}$ cells in an immunoprivileged site. Eur J Immunol 1997; 27(12): 3259-68.

[157] Brinchmann JE, Gaudernack G, Vartdal F. CD8+ T cells inhibit HIV replication in naturally infected CD4+ T cells. Evidence for a soluble inhibitor. J Immunol 1990; 144(8): 2961-6.

[158] Brodie SJ, Lewinsohn DA, Patterson BK, et al. In vivo migration and function of transferred HIV-1-specific cytotoxic T cells. Nat Med 1999; 5(1): 34-41.

[159] Roederer M, Dubs JG, Anderson MT, Raju PA, Herzenberg LA. CD8 naive $\mathrm{T}$ cell counts decrease progressively in HIV-infected adults. J Clin Invest 1995; 95(5): 2061-6.

[160] Mackewicz CE, Ortega HW, Levy JA. CD8+ cell anti-HIV activity correlates with the clinical state of the infected individual. J Clin Invest 1991; 87(4): 1462-6.

[161] Muthumani K, Bagarazzi M, Conway D, et al. Inclusion of Vpr accessory gene in a plasmid vaccine cocktail markedly reduces Nef vaccine effectiveness in vivo resulting in CD4 cell loss and increased viral loads in rhesus macaques. J Med Primatol 2002; 31(4-5): 179-85.

[162] Ayyavoo V, Muthumani K, Kudchodkar S, et al. HIV-1 viral protein $\mathrm{R}$ compromises cellular immune function in vivo. Int Immunol 2002; 14(1): 13-22.

[163] Conti L, Rainaldi G, Matarrese P, et al. The HIV-1 vpr protein acts as a negative regulator of apoptosis in a human lymphoblastoid $\mathrm{T}$ cell line: possible implications for the pathogenesis of AIDS. J Exp Med 1998; 187(3): 403-13.

[164] Moon HS, Yang JS. Role of HIV Vpr as a regulator of apoptosis and an effector on bystander cells. Mol Cells 2006; 21(1): 7-20.

[165] Bouzar AB, Villet S, Morin T, et al. Simian immunodeficiency virus $\mathrm{Vpr} / \mathrm{Vpx}$ proteins kill bystander noninfected CD4+ Tlymphocytes by induction of apoptosis. Virology 2004; 326(1): 4756.

[166] Azad AA. Could Nef and Vpr proteins contribute to disease progression by promoting depletion of bystander cells and prolonged survival of HIV-infected cells? Biochem Biophys Res Commun 2000; 267(3): 677-85.

[167] Meyaard L, Schuitemaker H, Miedema F. T-cell dysfunction in HIV infection: anergy due to defective antigen-presenting cell function? Immunol Today 1993; 14(4): 161-4.

[168] Groux H, Torpier G, Monte D, Mouton Y, Capron A, Ameisen JC. Activation-induced death by apoptosis in CD4+ $\mathrm{T}$ cells from human immunodeficiency virus-infected asymptomatic individuals. J Exp Med 1992; 175(2): 331-40.

[169] Yasuda J, Miyao T, Kamata M, Aida Y, Iwakura Y. T cell apoptosis causes peripheral $\mathrm{T}$ cell depletion in mice transgenic for the HIV-1 vpr gene. Virology 2001; 285(2): 181-92.

[170] Stewart SA, Poon B, Jowett JB, Chen IS. Human immunodeficiency virus type $1 \mathrm{Vpr}$ induces apoptosis following cell cycle arrest. J Virol 1997; 71(7): 5579-92.

[171] Li G, Park HU, Liang D, Zhao RY. Cell cycle G2/M arrest through an $\mathrm{S}$ phase-dependent mechanism by HIV-1 viral protein $\mathrm{R}$. Retrovirology 2010; 7: 59.

[172] Muthumani K, Zhang D, Hwang DS, et al. Adenovirus encoding HIV-1 Vpr activates caspase 9 and induces apoptotic cell death in both p53 positive and negative human tumor cell lines. Oncogene 2002; 21(30): 4613-25.

[173] Stewart SA, Poon B, Song JY, Chen IS. Human immunodeficiency virus type $1 \mathrm{vpr}$ induces apoptosis through caspase activation. J Virol 2000; 74(7): 3105-11.

[174] Majumder B, Venkatachari NJ, Schafer EA, Janket ML, Ayyavoo V. Dendritic cells infected with vpr-positive human immunodeficiency virus type 1 induce CD8+ T-cell apoptosis via upregulation of tumor necrosis factor alpha. J Virol 2007; 81(14): 7388-99.
[175] Richard J, Sindhu S, Pham TN, Belzile JP, Cohen EA. HIV-1 Vpr up-regulates expression of ligands for the activating NKG2D receptor and promotes NK cell-mediated killing. Blood 2010; 115(7): 1354-63.

[176] Ward J, Davis Z, DeHart J, et al. HIV-1 Vpr triggers natural killer cell-mediated lysis of infected cells through activation of the ATRmediated DNA damage response. PLoS Pathog 2009; 5(10): e1000613.

[177] Hong HS, Bhatnagar N, Ballmaier M, et al. Exogenous HIV-1 Vpr disrupts IFN-alpha response by plasmacytoid dendritic cells (pDCs) and subsequent pDC/NK interplay. Immunol Lett 2009; 125(2): 100-4.

[178] Muthumani K, Desai BM, Hwang DS, et al. HIV-1 Vpr and antiinflammatory activity. DNA Cell Biol 2004; 23(4): 239-47.

[179] Venkatachari NJ, Majumder B, Ayyavoo V. Human immunodeficiency virus (HIV) type $1 \mathrm{Vpr}$ induces differential regulation of $\mathrm{T}$ cell costimulatory molecules: direct effect of $\mathrm{Vpr}$ on $\mathrm{T}$ cell activation and immune function. Virology 2007; 358(2): 347-56.

[180] Muthumani K, Choo AY, Hwang DS, et al. HIV-1 Viral protein-r (Vpr) protects against lethal superantigen challenge while maintaining homeostatic $\mathrm{T}$ cell levels in vivo. Mol Ther 2005; 12(5): 910-21.

[181] Majumder B, Venkatachari NJ, O'Leary S, Ayyavoo V. Infection with Vpr-positive human immunodeficiency virus type 1 impairs NK cell function indirectly through cytokine dysregulation of infected target cells. J Virol 2008; 82(14): 7189-200.

[182] Auphan N, DiDonato JA, Rosette C, Helmberg A, Karin M. Immunosuppression by glucocorticoids: inhibition of NF-kappa B activity through induction of I kappa B synthesis. Science 1995; 270(5234): 286-90.

[183] Scheinman RI, Cogswell PC, Lofquist AK, Baldwin AS, Jr. Role of transcriptional activation of I kappa B alpha in mediation of immunosuppression by glucocorticoids. Science 1995; 270(5234): 283-6.

[184] Ayyavoo V, Mahboubi A, Mahalingam S, et al. HIV-1 Vpr suppresses immune activation and apoptosis through regulation of nuclear factor kappa B. Nat Med 1997; 3(10): 1117-23.

[185] Muthumani K, Kudchodkar S, Papasavvas E, Montaner LJ, Weiner DB, Ayyavoo V. HIV-1 Vpr regulates expression of beta chemokines in human primary lymphocytes and macrophages. J Leukoc Biol 2000; 68(3): 366-72.

[186] Muthumani K, Choo AY, Zong WX, et al. The HIV-1 Vpr and glucocorticoid receptor complex is a gain-of-function interaction that prevents the nuclear localization of PARP-1. Nat Cell Biol 2006; 8(2): 170-9.

[187] Hoshino S, Konishi M, Mori M, et al. HIV-1 Vpr induces TLR4/MyD88-mediated IL-6 production and reactivates viral production from latency. J Leukoc Biol 2010; 87(6): 1133-43.

[188] Varin A, Decrion AZ, Sabbah E, et al. Synthetic Vpr protein activates activator protein-1, c-Jun N-terminal kinase, and NFkappaB and stimulates HIV-1 transcription in promonocytic cells and primary macrophages. J Biol Chem 2005; 280(52): 42557-67.

[189] Roux P, Alfieri C, Hrimech M, Cohen EA, Tanner JE. Activation of transcription factors NF-kappaB and NF-IL-6 by human immunodeficiency virus type 1 protein $\mathrm{R}(\mathrm{Vpr})$ induces interleukin8 expression. J Virol 2000; 74(10): 4658-65.

[190] Baehrecke EH. How death shapes life during development. Nat Rev Mol Cell Biol 2002; 3(10): 779-87.

[191] Fooksman DR, Vardhana S, Vasiliver-Shamis G, et al. Functional anatomy of $\mathrm{T}$ cell activation and synapse formation. Annu Rev Immunol 2010; 28: 79-105.

[192] Zhang J, Xu X, Liu Y. Activation-induced cell death in T cells and autoimmunity. Cell Mol Immunol 2004; 1(3): 186-92.

[193] Krammer PH, Arnold R, Lavrik IN. Life and death in peripheral T cells. Nat Rev Immunol 2007; 7(7): 532-42.

[194] Cossarizza A. Apoptosis and HIV infection: about molecules and genes. Curr Pharm Des 2008; 14(3): 237-44.

[195] Cossarizza A, Ortolani C, Mussini C, et al. Massive activation of immune cells with an intact $\mathrm{T}$ cell repertoire in acute human immunodeficiency virus syndrome. J Infect Dis 1995; 172(1): 10512.

[196] Norris PJ, Pappalardo BL, Custer B, Spotts G, Hecht FM, Busch MP. Elevations in IL-10, TNF-alpha, and IFN-gamma from the earliest point of HIV Type 1 infection. AIDS Res Hum Retroviruses 2006; 22(8): 757-62. 
[197] Picker LJ. Immunopathogenesis of acute AIDS virus infection. Curr Opin Immunol 2006; 18(4): 399-405.

[198] Douek DC, Brenchley JM, Betts MR, et al. HIV preferentially infects HIV-specific CD4+ T cells. Nature 2002; 417(6884): 95-8.

[199] Chavez-Galan L, Arenas-Del Angel MC, Zenteno E, Chavez R, Lascurain R. Cell death mechanisms induced by cytotoxic lymphocytes. Cell Mol Immunol 2009; 6(1): 15-25.

[200] Liu Y, McNevin JP, Holte S, McElrath MJ, Mullins JI. Dynamics of viral evolution and CTL responses in HIV-1 infection. PLoS ONE 2011; 6(1): e15639.

[201] Rivera-Toledo E, Lopez-Balderas N, Huerta L, Lamoyi E, Larralde C. Decreased CD4 and wide-ranging expression of other immune receptors after HIV-envelope-mediated formation of syncytia in vitro. Arch Virol 2010; 155(8): 1205-16.

[202] Ferri KF, Jacotot E, Leduc P, Geuskens M, Ingber DE, Kroemer G. Apoptosis of syncytia induced by the HIV-1-envelope glycoprotein complex: influence of cell shape and size. Exp Cell Res 2000; 261(1): 119-26.

[203] Perfettini JL, Nardacci R, Bourouba M, et al. Critical involvement of the ATM-dependent DNA damage response in the apoptotic demise of HIV-1-elicited syncytia. PLoS ONE 2008; 3(6): e2458.

[204] Sodora DL, Silvestri G. Immune activation and AIDS pathogenesis. AIDS 2008; 22(4): 439-46.

[205] Holm GH, Gabuzda D. Distinct mechanisms of CD4+ and CD8+ T-cell activation and bystander apoptosis induced by human immunodeficiency virus type 1 virions. J Virol 2005; 79(10): 6299311.

[206] Kamata M, Nagaoka Y, Chen IS. Reassessing the role of APOBEC3G in human immunodeficiency virus type 1 infection of quiescent CD4+ T-cells. PLoS Pathog 2009; 5(3): e1000342.

[207] Zhou Y, Zhang H, Siliciano JD, Siliciano RF. Kinetics of human immunodeficiency virus type 1 decay following entry into resting CD4+ T cells. J Virol 2005; 79(4): 2199-210.

[208] Doitsh G, Cavrois M, Lassen KG, et al. Abortive HIV infection mediates CD4 $\mathrm{T}$ cell depletion and inflammation in human lymphoid tissue. Cell 2010; 143(5): 789-801.

[209] Miura Y, Koyanagi Y. Death ligand-mediated apoptosis in HIV infection. Rev Med Virol 2005; 15(3): 169-78.

[210] Gasper-Smith N, Crossman DM, Whitesides JF, et al. Induction of plasma (TRAIL), TNFR-2, Fas ligand, and plasma microparticles after human immunodeficiency virus type 1 (HIV-1) transmission: implications for HIV-1 vaccine design. J Virol 2008; 82(15): 770010.

[211] Aillet F, Masutani H, Elbim C, et al. Human immunodeficiency virus induces a dual regulation of $\mathrm{Bcl}-2$, resulting in persistent infection of CD4(+) T- or monocytic cell lines. J Virol 1998; 72(12): 9698-705.

[212] Oyaizu N, McCloskey TW, Coronesi M, Chirmule N, Kalyanaraman VS, Pahwa S. Accelerated apoptosis in peripheral blood mononuclear cells (PBMCs) from human immunodeficiency virus type-1 infected patients and in CD4 cross-linked PBMCs from normal individuals. Blood 1993; 82(11): 3392-400.

[213] Herbein G, Gras G, Khan KA, Abbas W. Macrophage signaling in HIV-1 infection. Retrovirology 2010; 7: 34.

[214] Vlahakis SR, Algeciras-Schimnich A, Bou G, et al. Chemokinereceptor activation by env determines the mechanism of death in HIV-infected and uninfected T lymphocytes. J Clin Invest 2001; 107(2): 207-15.

[215] Somma F, Tuosto L, Gilardini Montani MS, Di Somma MM, Cundari E, Piccolella E. Engagement of CD4 before TCR triggering regulates both Bax- and Fas (CD95)-mediated apoptosis. J Immunol 2000; 164(10): 5078-87.

[216] James CO, Huang MB, Khan M, Garcia-Barrio M, Powell MD, Bond VC. Extracellular Nef protein targets CD4+ T cells for apoptosis by interacting with CXCR4 surface receptors. J Virol 2004; 78(6): 3099-109.

[217] McCloskey TW, Ott M, Tribble E, et al. Dual role of HIV Tat in regulation of apoptosis in T cells. J Immunol 1997; 158(2): 1014-9.

[218] Gougeon ML. Apoptosis as an HIV strategy to escape immune attack. Nat Rev Immunol 2003; 3(5): 392-404.

[219] Estaquier J, Idziorek T, Zou W, et al. T helper type 1/T helper type 2 cytokines and $\mathrm{T}$ cell death: preventive effect of interleukin 12 on activation-induced and CD95 (FAS/APO-1)-mediated apoptosis of CD4+ $\mathrm{T}$ cells from human immunodeficiency virus-infected persons. J Exp Med 1995; 182(6): 1759-67.
[220] Katsikis PD, Wunderlich ES, Smith CA, Herzenberg LA. Fas antigen stimulation induces marked apoptosis of $\mathrm{T}$ lymphocytes in human immunodeficiency virus-infected individuals. J Exp Med 1995; 181(6): 2029-36.

[221] Mueller YM, De Rosa SC, Hutton JA, et al. Increased CD95/Fasinduced apoptosis of HIV-specific CD8(+) T cells. Immunity 2001 15(6): 871-82.

[222] Merrill JE, Koyanagi Y, Chen IS. Interleukin-1 and tumor necrosis factor alpha can be induced from mononuclear phagocytes by human immunodeficiency virus type 1 binding to the CD4 receptor. J Virol 1989; 63(10): 4404-8.

[223] Zheng L, Fisher G, Miller RE, Peschon J, Lynch DH, Lenardo MJ. Induction of apoptosis in mature $\mathrm{T}$ cells by tumour necrosis factor. Nature 1995; 377(6547): 348-51.

[224] Grell M, Douni E, Wajant H, et al. The transmembrane form of tumor necrosis factor is the prime activating ligand of the $80 \mathrm{kDa}$ tumor necrosis factor receptor. Cell 1995; 83(5): 793-802.

[225] Lahdevirta J, Maury CP, Teppo AM, Repo H. Elevated levels of circulating cachectin/tumor necrosis factor in patients with acquired immunodeficiency syndrome. Am J Med 1988; 85(3): 289-91.

[226] Blair PJ, Boise LH, Perfetto SP, et al. Impaired induction of the apoptosis-protective protein Bcl-xL in activated PBMC from asymptomatic HIV-infected individuals. J Clin Immunol 1997; 17(3): 234-46

[227] Dockrell DH, Badley AD, Villacian JS, et al. The expression of Fas Ligand by macrophages and its upregulation by human immunodeficiency virus infection. J Clin Invest 1998; 101(11): 2394-405.

[228] Tateyama M, Oyaizu N, McCloskey TW, Than S, Pahwa S. CD4 T lymphocytes are primed to express Fas ligand by CD4 crosslinking and to contribute to CD8 T-cell apoptosis via Fas/FasL death signaling pathway. Blood 2000; 96(1): 195-202.

[229] Westendorp MO, Frank R, Ochsenbauer C, et al. Sensitization of T cells to CD95-mediated apoptosis by HIV-1 Tat and gp120. Nature 1995; 375(6531): 497-500.

[230] Schacker TW, Brenchley JM, Beilman GJ, et al. Lymphatic tissue fibrosis is associated with reduced numbers of naive CD4+ T cells in human immunodeficiency virus type 1 infection. Clin Vaccine Immunol 2006; 13(5): 556-60

[231] Sprent J, Cho JH, Boyman O, Surh CD. T cell homeostasis. Immunol Cell Biol 2008; 86(4): 312-9.

[232] Takada K, Jameson SC. Naive T cell homeostasis: from awareness of space to a sense of place. Nat Rev 2009; 9(12): 823-32.

[233] Rosenzweig M, Clark DP, Gaulton GN. Selective thymocyte depletion in neonatal HIV-1 thymic infection. AIDS 1993; 7(12): 1601-5.

[234] Kourtis AP, Ibegbu C, Nahmias AJ, et al. Early progression of disease in HIV-infected infants with thymus dysfunction. N Engl J Med 1996; 335(19): 1431-6.

[235] Gaulton GN. Viral pathogenesis and immunity within the thymus. Immunol Res 1998; 17(1-2): 75-82.

[236] Douek DC, McFarland RD, Keiser PH, et al. Changes in thymic function with age and during the treatment of HIV infection. Nature 1998; 396(6712): 690-5.

[237] Vigano A, Vella S, Saresella M, et al. Early immune reconstitution after potent antiretroviral therapy in HIV-infected children correlates with the increase in thymus volume. AIDS 2000; 14(3): 251-61.

[238] McCune JM. Thymic function in HIV-1 disease. Semin Immunol 1997; 9(6): 397-404

[239] Knutsen AP, Roodman ST, Freeman JJ, Mueller KR, Bouhasin JD. Inhibition of thymopoiesis of CD34+ cell maturation by HIV-1 in an in vitro CD34+ cell and thymic epithelial organ culture model. Stem Cells 1999; 17(6): 327-38.

[240] Bonyhadi ML, Su L, Auten J, McCune JM, Kaneshima H. Development of a human thymic organ culture model for the study of HIV pathogenesis. AIDS Res Hum Retroviruses 1995; 11(9): 1073-80.

[241] Sodora DL, Milush JM, Ware F, et al. Decreased levels of recent thymic emigrants in peripheral blood of simian immunodeficiency virus-infected macaques correlate with alterations within the thymus. J Virol 2002; 76(19): 9981-90.

[242] Rothe M, Chene L, Nugeyre MT, Braun J, Barre-Sinoussi F, Israel N. Contact with thymic epithelial cells as a prerequisite for 
cytokine-enhanced human immunodeficiency virus type 1 replication in thymocytes. J Virol 1998; 72(7): 5852-61.

[243] Ho Tsong Fang R, Colantonio AD, Uittenbogaart CH. The role of the thymus in HIV infection: a 10 year perspective. AIDS 2008; 22(2): 171-84.

[244] Stanley SK, McCune JM, Kaneshima H, et al. Human immunodeficiency virus infection of the human thymus and disruption of the thymic microenvironment in the SCID-hu mouse. J Exp Med 1993; 178(4): 1151-63.

[245] Maroder M, Scarpa S, Screpanti I, et al. Human immunodeficiency virus type 1 tat protein modulates fibronectin expression in thymic epithelial cells and impairs in vitro thymocyte development. Cell Immunol 1996; 168(1): 49-58.

[246] Haase AT. Population biology of HIV-1 infection: viral and CD4+ $\mathrm{T}$ cell demographics and dynamics in lymphatic tissues. Annu Rev Immunol 1999; 17: 625-56.

[247] Link A, Vogt TK, Favre S, et al. Fibroblastic reticular cells in lymph nodes regulate the homeostasis of naive T cells. Nat Immun 2007; 8(11): 1255-65.

[248] Sixt M, Kanazawa N, Selg M, et al. The conduit system transports soluble antigens from the afferent lymph to resident dendritic cells in the T cell area of the lymph node. Immunity 2005; 22(1): 19-29.

[249] Zeng M, Smith AJ, Wietgrefe SW, et al. Cumulative mechanisms of lymphoid tissue fibrosis and T cell depletion in HIV-1 and SIV infections. J Clin invest 2011; 121(3): 998-1008.

[250] Zeng M, Haase AT, Schacker TW. Lymphoid tissue structure and HIV-1 infection: life or death for T cells. Trends Immunol 2012; 33(6): 306-14

[251] Margolick JB, Volkman DJ, Folks TM, Fauci AS. Amplification of HTLV-III/LAV infection by antigen-induced activation of T cells and direct suppression by virus of lymphocyte blastogenic responses. J Immunol 1987; 138(6): 1719-23.

[252] Zack JA, Cann AJ, Lugo JP, Chen IS. HIV-1 production from infected peripheral blood T cells after HTLV-I induced mitogenic stimulation. Science 1988; 240(4855): 1026-9.

[253] Dooms H, Abbas AK. Control of CD4+ T-cell memory by cytokines and costimulators. Immunol Rev 2006; 211: 23-38.

[254] Hermankova M, Siliciano JD, Zhou Y, et al. Analysis of human immunodeficiency virus type 1 gene expression in latently infected resting CD4+ T lymphocytes in vivo. J Virol 2003; 77(13): 738392 .
[255] Brooks DG, Hamer DH, Arlen PA, et al. Molecular characterization, reactivation, and depletion of latent HIV Immunity 2003; 19(3): 413-23.

[256] Tong-Starksen SE, Luciw PA, Peterlin BM. Human immunodeficiency virus long terminal repeat responds to T-cell activation signals. Proc Natl Acad Sci USA 1987; 84(19): 6845-9.

[257] Nabel G, Baltimore D. An inducible transcription factor activates expression of human immunodeficiency virus in T cells. Nature 1987; 326(6114): 711-3.

[258] Meyerhans A, Vartanian JP, Hultgren C, et al. Restriction and enhancement of human immunodeficiency virus type 1 replication by modulation of intracellular deoxynucleoside triphosphate pools. J Virol 1994; 68(1): 535-40.

[259] Chun TW, Engel D, Berrey MM, Shea T, Corey L, Fauci AS. Early establishment of a pool of latently infected, resting CD4(+) T cells during primary HIV-1 infection. Proc Natl Acad Sci USA 1998; 95(15): 8869-73

[260] Lassen KG, Bailey JR, Siliciano RF. Analysis of human immunodeficiency virus type 1 transcriptional elongation in resting CD4+ T cells in vivo. J Virol 2004; 78(17): 9105-14.

[261] Finzi D, Blankson J, Siliciano JD, et al. Latent infection of CD4+ T cells provides a mechanism for lifelong persistence of HIV-1, even in patients on effective combination therapy. Nat Med 1999; 5(5): 512-7.

[262] Siliciano JD, Kajdas J, Finzi D, et al. Long-term follow-up studies confirm the stability of the latent reservoir for HIV-1 in resting CD4+ T cells. Nat Med 2003; 9(6): 727-8.

[263] Chomont N, El-Far M, Ancuta P, et al. HIV reservoir size and persistence are driven by $\mathrm{T}$ cell survival and homeostatic proliferation. Nat Med 2009; 15(8): 893-900.

[264] Swingler S, Brichacek B, Jacque JM, Ulich C, Zhou J, Stevenson M. HIV-1 Nef intersects the macrophage CD40L signalling pathway to promote resting-cell infection. Nature 2003; 424(6945): 213-9.

[265] Blaak H, van't Wout AB, Brouwer M, Hooibrink B, Hovenkamp E, Schuitemaker H. In vivo HIV-1 infection of CD45RA(+)CD4(+) T cells is established primarily by syncytium-inducing variants and correlates with the rate of CD4(+) T cell decline. Proc Natl Acad Sci USA 2000; 97(3): 1269-74.

(C) Abbas and Herbein; Licensee Bentham Open.

This is an open access article licensed under the terms of the Creative Commons Attribution Non-Commercial License (http: //creativecommons.org/licenses/by$\mathrm{nc} / 3.0 /$ ) which permits unrestricted, non-commercial use, distribution and reproduction in any medium, provided the work is properly cited. 